This is the final peer-reviewed accepted manuscript of:

AMOROSI, ALESSANDRO; BRUNO, LUIGI; Cleveland, David M.; MORELLI, AGNESE; Hong, Wan: Paleosols and associated channel-belt sand bodies from a continuously subsiding late quaternary system (Po basin, Italy): New insights into continental sequence stratigraphy. GEOLOGICAL SOCIETY OF AMERICA BULLETIN 129. 0016-7606

DOI: $10.1130 / B 31575.1$

The final published version is available online at:

http://dx.doi.org/10.1130/B31575.1

Rights / License:

The terms and conditions for the reuse of this version of the manuscript are specified in the publishing policy. For all terms of use and more information see the publisher's website.

This item was downloaded from IRIS Università di Bologna (https://cris.unibo.it/)

When citing, please refer to the published version. 


\title{
Paleosols and associated channel-belt sand bodies from a continuously subsiding late Quaternary system (Po Basin, Italy): New insights into continental sequence stratigraphy
}

\author{
Alessandro Amorosi ${ }^{1, \dagger}$, Luigi Bruno ${ }^{1}$, David M. Cleveland ${ }^{2}$, Agnese Morelli ${ }^{1}$, and Wan Hong ${ }^{3}$ \\ ${ }^{1}$ Department of Biological, Geological and Environmental Sciences, University of Bologna, Via Zamboni 67, 40126 Bologna, Italy \\ ${ }^{2}$ ExxonMobil Development Company, 22777 Springwoods Village Parkway, Spring, Texas 77389, USA \\ ${ }^{3}$ KIGAM Korea Institute of Geoscience and Mineral Resources, 92 Gwahangro, Yuseong-gu, Daejeon Metropolitan City, Korea
}

\section{ABSTRACT}

Previous sequence-stratigraphic work has emphasized the key role of paleosols and associated sand-dominated fluvial bodies as key features for interpreting alluvial architecture. The temporal resolution of the ancient record is, however, insufficient to fully explain the complex relationship between soil formation and the evolution of fluvial systems under changing sea-level and climate conditions. In this paper, we present a detailed record of paleosol-channel belt relationships reconstructed from the subsurface of a rapidly subsiding region (Po Plain, Italy) that spans almost all of the last glacial-interglacial cycle ( 120 k.y.). The studied succession preserves a systematic bipartite zonation into a thick paleosol-bearing segment close to the basin margin and a sand-dominated interval, with vertically amalgamated channel belts, in an axial position. Individual paleosols are weakly developed and represent key stratigraphic markers that can be traced basinwide into adjacent, essentially contemporaneous, unconfined channel-belt deposits. Unlike conventional models of late Quaternary alluvial-coastal plain systems, no persistent incised valley was established in the Po system during the last glacial-interglacial cycle. Continuous accommodation was the key depositional control on alluvial stratigraphy during the prolonged ( 90 k.y.) phase of late Pleistocene sea-level fall, which led to the deposition of a thick, dominantly aggradational alluvial succession. The development of shallowly incised, short-lived valley systems took place only at the transition to glacial stages associated with substantial sea-level drop (marine oxygen isotope stage

‘alessandro.amorosi@unibo.it
[MIS] 3-2 transition, and possibly MIS 5-4 transition). This study shows that in rapidly subsiding settings with high rates of sedimentation, incised valley systems may be replaced by aggradationally stacked, essentially nonincised fluvial bodies. In these cases, overbank packages bounded by immature paleosols represent the most likely alternative to the highly weathered interfluve paleosol predicted by classic sequence-stratigraphic models. Fourth-order sequence boundaries and lower-rank erosional surfaces may be easily confused at the $\sim 100$ k.y. scale, and transgressive surfaces, defining the onset of retrogradation, may become the most readily identifiable sequence-stratigraphic surfaces.

\section{INTRODUCTION}

The development of an integrated model that includes paleosols, fluvial facies, and associated bounding surfaces is crucial to prediction of nonmarine stratigraphic architecture. In sequence-stratigraphic studies, integration of paleopedological data with regional sedimentological and stratigraphic information has resulted in a powerful approach to the genetic interpretation of interfluve surfaces and their associated paleovalley systems (McCarthy and Plint, 1998; McCarthy et al., 1999).

Previous work from the ancient record has documented paleosol-channel belt relationships from superbly exposed outcrops, including the Eocene Willwood Formation (Bown and Kraus, 1981; Kraus and Bown, 1993; Kraus, 2002), the Cenomanian Dunvegan Formation (McCarthy et al., 1999; McCarthy and Plint, 2003), the Jurassic Morrison Formation (Demko et al., 2004), the Triassic Chinle Formation (Cleveland et al., 2007; Dubiel and Hasiotis, 2011; Trendell et al., 2012), and the Carboniferous cyclothems of Nova Scotia (Gibling and Bird, 1994; Tan- don and Gibling, 1994, 1997). However, when charged with predicting the extent to which sea-level or climate changes will affect regional configuration and stratigraphic architecture on time scales typically attributed to autogenic processes (on the order of few thousand years), these models suffer from poor chronologic resolution and may yield a range of possible interpretations (Wright and Marriott, 1993; Kraus and Aslan, 1999; Atchley et al., 2004).

Recent stratigraphic studies have focused on Quaternary depositional systems because of their high-resolution climatic and eustatic records (Blum and Törnqvist, 2000). The Quaternary, for which dense, high-resolution sealevel and climate data are available, represents an interval of time where process controls are well established. In this regard, well-constrained Quaternary systems, especially in close temporal proximity to the Holocene, can be used to develop reliable predictive models in ancient rocks (Blum et al., 2013).

The use of soil in mapping Quaternary sediments is a well-established methodology (Morrison, 1978). Quaternary pedostratigraphy, however, has focused predominantly on paleosols developed on fluvial terraces (Bestland, 1997; Ufnar, 2007; Eppes et al., 2008) or parts of loesspaleosol sequences (Kemp et al., 1995; Zhisheng and Porter, 1997; Berger et al., 2002), with the aim being to reconstruct pedosedimentary processes, climate change, or landscape evolution (Mahaney et al., 1993; Feng and Wang, 2005; Kemp et al., 2006; Schellenberger and Veit, 2006; Sheldon and Tabor, 2009).

Owing to the laterally limited extent of core and well-log information, and subsequent problems with correlation, high-resolution stratigraphy of Quaternary paleosol-bearing successions has seldom been applied to alluvial deposits in the subsurface and to core analysis, with few exceptions (Wallinga et al., 2004; Srivastava et al., 
2010; Tsatskin et al., 2015). As a result, substantial gaps in knowledge remain about the temporal significance of stratigraphic hiatuses when comparing outcrop to core, or the Quaternary to the ancient record.

The stratigraphy of the coastal portion of the Po Plain has been extensively studied over the past $20 \mathrm{yr}$ based on refined core analysis (Amorosi et al., 1999, 2004, 2005, 2008; Stefani and Vincenzi, 2005). However, owing to the difficulty of tracing reliable stratigraphic markers in fully nonmarine deposits, very few detailed studies have documented the subsurface stratigraphy in the most proximal, entirely nonmarine segment of the plain (Amorosi et al., 2014, 2015). The recent application of pedostratigraphic concepts at the Po Basin margin, in the Bologna area (Fig. 1), has led to very promising results from the perspective of fluvial architecture, highlighting the presence in the subsurface of a prominent suite of laterally extensive, weakly developed paleosols formed during the prolonged phase of sea-level fall that accompanied the late Pleistocene glacial period. In particular, two major phases of pedogenesis associated with channel-belt development were identified on the basis of radiocarbon dating (Amorosi et al., 2014): (1) at the marine oxygen isotope stage (MIS) 3-2 transition (29-26 ka), and (2) at the Pleistocene-Holocene boundary, coincident with the Younger Dryas cold event (13-11 ka).

The primary aim of this article, which focuses on a $3800 \mathrm{~km}^{2}$ portion of the subsiding southern Po Plain (Fig. 1), is to outline, through a chronologically well-constrained subsurface investigation, the development of a wide array of laterally extensive, weakly developed paleosols during the last glacial period, i.e., under generalized conditions of sea-level fall. Specific objectives are: (1) to offer, from a continuously subsiding system, an alternative model to valley incision associated with base-level fall; (2) to propose a modern analog perspective on the genetic relations between paleosols and adjacent channel-belt systems on higher-resolution time scales than those normally available from the ancient record; and (3) to provide documentation of geotechnical core logging (piezocone penetration tests and pocket penetration values) as a powerful tool for paleosol identification and tracking in unconsolidated deposits.

\section{GEOLOGIC SETTING}

The Po Plain is the surface expression of a rapidly subsiding foreland basin in direct connection in the east with the Adriatic Sea. The Po Basin is bounded to the south by the Apennines and to the north by the southern Alps
(Fig. 2). These two mountain chains are foldand-thrust belts with opposite structural vergence (Ricci Lucchi, 1986; Doglioni, 1993), and they represent distinct sources of sediment for the Po Basin. With a total length of $652 \mathrm{~km}$, the Po River is the longest river in Italy. It flows from the western Alps eastward into the Adriatic Sea, and it receives a number of transverse tributaries from both mountain chains.

The Pliocene-Quaternary sedimentary fill of the Po Basin may exceed $7000 \mathrm{~m}$ in the thickest depocenters (Pieri and Groppi, 1981; Castellarin et al., 1985). The overall basin stratigraphy has been thoroughly depicted in the last three decades through integrated seismic analysis (Pieri and Groppi, 1981), magnetostratigraphic studies (Muttoni et al., 2003; Scardia et al., 2006), and well-log interpretation (Ori, 1993). These studies, aimed first at hydrocarbon research (AGIP Mineraria, 1959; AGIP, 1977) and second at aquifer distribution (Regione EmiliaRomagna and ENI-AGIP, 1998; Regione Lombardia and E.N.I. Divisione AGIP, 2002), led to the subdivision of the basin fill into numerous third-order depositional sequences separated by regional unconformities (Fig. 2). The youngest sequence, the lower boundary of which has an estimated age of ca. 0.87 Ma (Muttoni et al., 2003), is subdivided into a number of lowerrank (fourth-order), transgressive-regressive

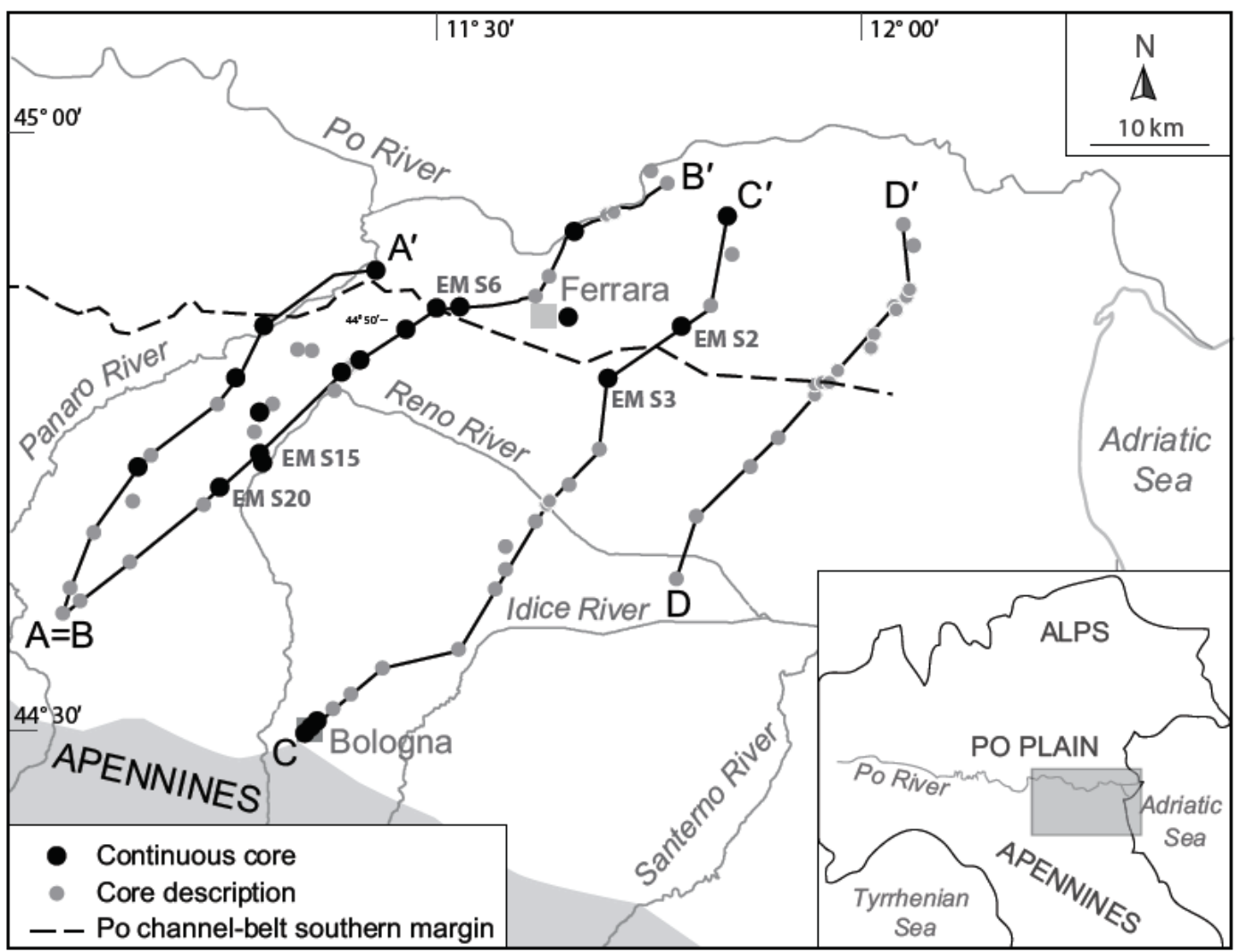

Figure 1. The southern Po Plain, Italy, with locations of the cross sections and reference cores discussed in the text. 

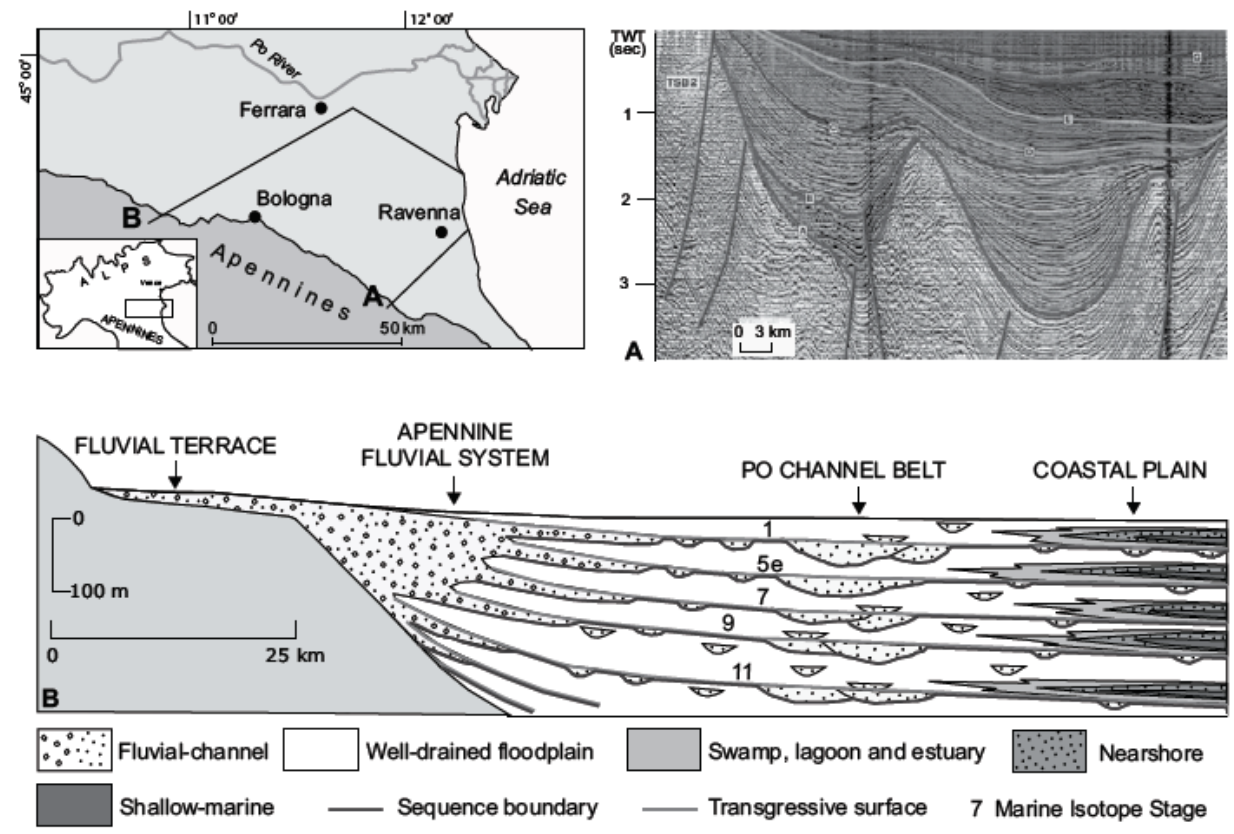

Figure 2. (A) Seismic profile showing the Pliocene-Quaternary Po Basin fill and its subdivision into third-order depositional sequences (grayscale units; from Regione Emilia-Romagna and ENI-AGIP, 1998). TWT-two-way traveltime. (B) Fourth-order transgressive-regressive sequences formed in response to Milankovitch forcing (from Amorosi et al., 2016). Cross section line shown in inset map.

(T-R) cycles (Fig. 2), where Milankovitchscale orbital forcing (100 k.y.) was recognized as a driving factor, based on pollen evidence (Amorosi et al., 2004, 2008, 2016).

$T-R$ cycles are easily recognized in the coastal plain, where the transgressive surfaces mark the abrupt boundary between alluvial glacial deposits and overlying, coastal to shallowmarine interglacial facies (Fig. 2). Close to the basin margin, at the Apennines foothills, and beneath the modem Po River, the T-R cycles are almost entirely characterized by nonmarine deposits. In this context, based on pollen evidence, the transgressive surface (TS) has been traced approximately at the transition from laterally amalgamated fluvial bodies, formed under glacial conditions, to isolated channels, characteristic of interglacial periods with an increase in accommodation (Amorosi et al., 2008).

\section{METHODS}

This study relied upon an extensive network of cores, well logs, and piezocone penetration tests (Geological, Seismic and Soil Survey of EmiliaRomagna database) covering the southern part of the Po Plain. From a total of several hundred boreholes, we selected 16 recently drilled cores as key cores for our analysis. Coring was executed with a continuous perforating system to guarantee an undisturbed stratigraphy. Sediment cores, 24-52 m long, were investigated and correlated from a sedimentological perspective. Four additional cores (EM S2, S3, S6, and S15 in Fig. 1), up to $52 \mathrm{~m}$ long, were recovered as part of an extensive research and coring program initiated by ExxonMobil Upstream Research Company. The cores were opened with a lengthwise cut. Lithofacies characteristics, sediment texture, grain size, color, and accessory materials (fossils, plant and wood fragments) were examined, and pocket penetrometer (PP) values were collected from fine-grained deposits.

In total, 52 field log descriptions, 69 waterwell cuttings, and 118 (piezo)cone penetration tests (CPTU) were selected to develop a regional scheme of stratigraphic architecture. Facies associations identified in core were calibrated against the CPTU tests and used for stratigraphic correlations throughout the study area. More specifically, field log interpretations provided PP values and detailed information about color, lithology, accessory materials, and reaction to $\mathrm{HCl}$, while water-well logs enabled the identification of major sand bodies. Finally, CPTU tests were used, after calibration with adjacent boreholes, for facies characterization and lateral tracking of sedimentary bodies, as shown in Amorosi and Marchi (1999).

The stratigraphic architecture was then reconstructed on the basis of depositional facies correlation throughout the study area. Careful consideration was given to the identification and lateral tracing of weakly developed paleosols as key surfaces on a regional scale. No well-developed paleosols were observed in cored intervals.

The chronostratigraphic framework was defined by a total of 100 radiocarbon dates, 44 of which are unpublished. See Table DR1 for a complete list of all radiocarbon dated material, including core depth, uncalibrated/calibrated ages, $2 \sigma$ ranges, facies associations, and references. ${ }^{1}$ Bulk samples were collected from the innermost portion of the cores to avoid contamination by drilling fluid. The samples were desiccated, ground, passed through $0.05 \mathrm{~mm}$ sieves, and then cleaned through acid-alkaliacid pretreatment. Twenty samples were dated using accelerator mass spectrometry (AMS) at Korea Institute of Geoscience and Mineral Resources (KIGAM) Laboratory (Daejeon City, Korea), 22 at Laboratory of Ion Beam Physics (ETH, Zurich, Switzerland), 15 at Beta Analytic (Miami, Florida), 12 at La Sapienza Laboratory (Rome, Italy), six at Center for Isotopic Research on the Cultural and Environmental Heritage (CIRCE) Laboratory (Caserta, Italy), and four at Lodyc laboratory (Paris, France). Twenty-one samples were analyzed at Enea Radiocarbon Laboratory (Bologna, Italy) using liquid scintillation counting. The ${ }^{14} \mathrm{C}$ dates were calibrated with Oxcal 4.2 (Ramsey and Lee, 2013), using the Intcal13 calibration curve (Reimer et al., 2013). Since the detection limit of the various methods is $\sim 50$ k.y. B.P. (Reimer et al., 2013), six radiometric dates that yielded calibrated ages older than 40 k.y. B.P. (see footnote 1 ), and particularly two ages older than 45 k.y. B.P. (cores 203 S1 and EM S3) should be considered with caution. However, we note that these age uncertainties may affect correlation of the oldest paleosols, which are not the focus of this research.

\section{PALEOSOL IDENTIFICATION AND TRACING BY CPTU ANALYSIS}

Pedogenically modified horizons (Fig. 3) represent key markers for the high-resolution stratigraphic analysis of the Po system. In particular, buried soils mark regional hiatuses with distinct engineering properties that can be recognized in various types of geotechnical data (Fig. 4), thus facilitating correlation between cores. In this work, stratigraphic correlations of weakly developed paleosols allowed a basin-scale analysis to be accomplished for the first time, over a large portion of the Po Basin.

${ }^{1}$ GSA Data Repository item 2016318, complete list of all radiocarbon dated material shown in Figures

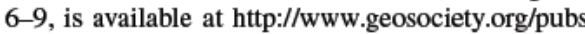
/ft2016.htm or by request to editing @ geosociety.org. 
YD paleosol

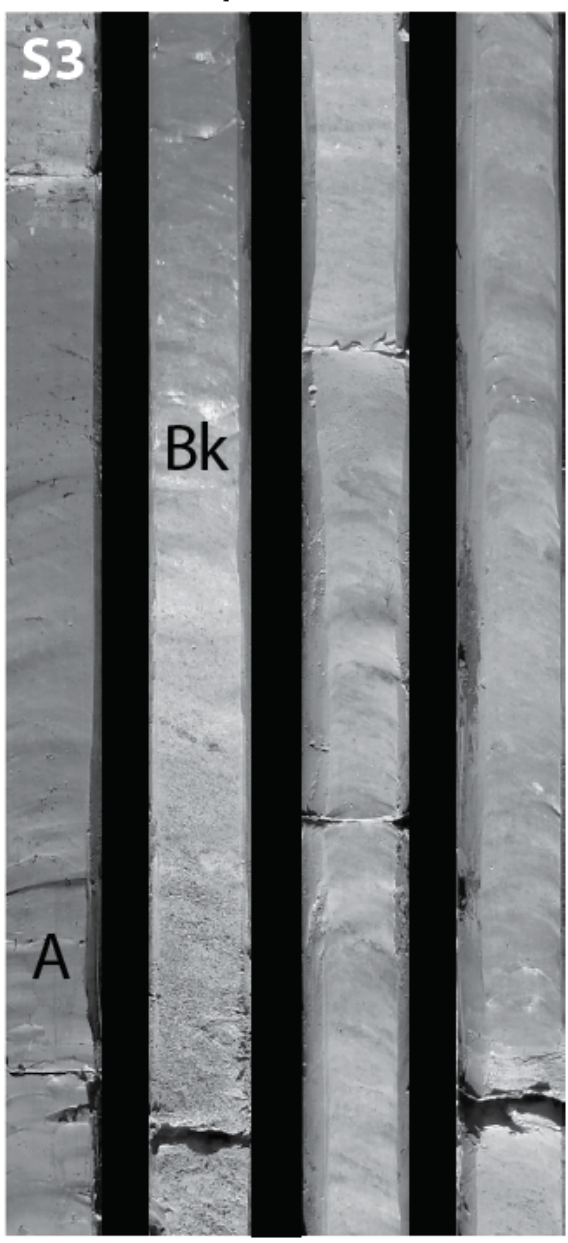

LGM paleosol

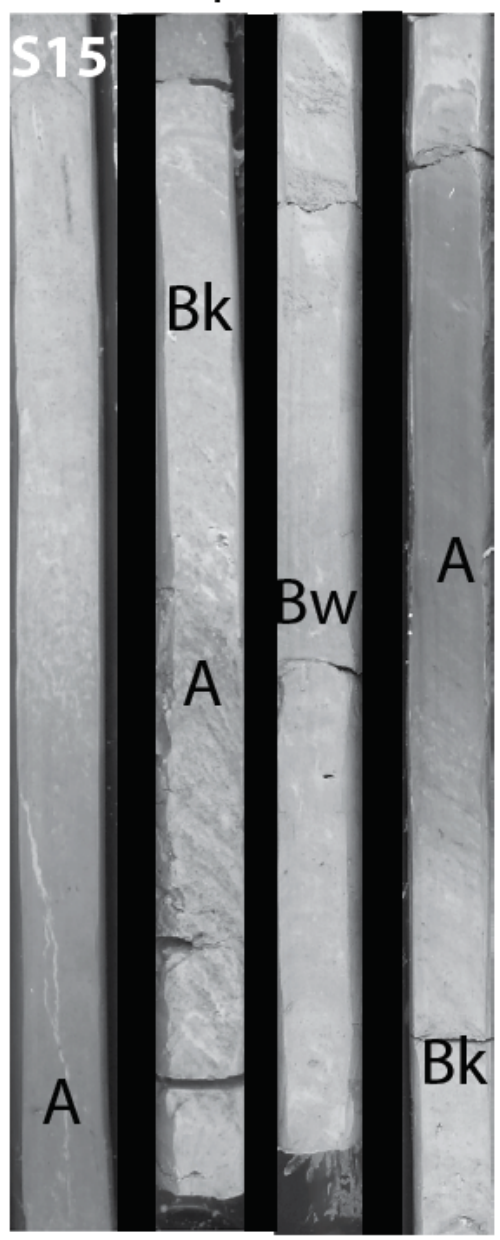

MIS 3 paleosols

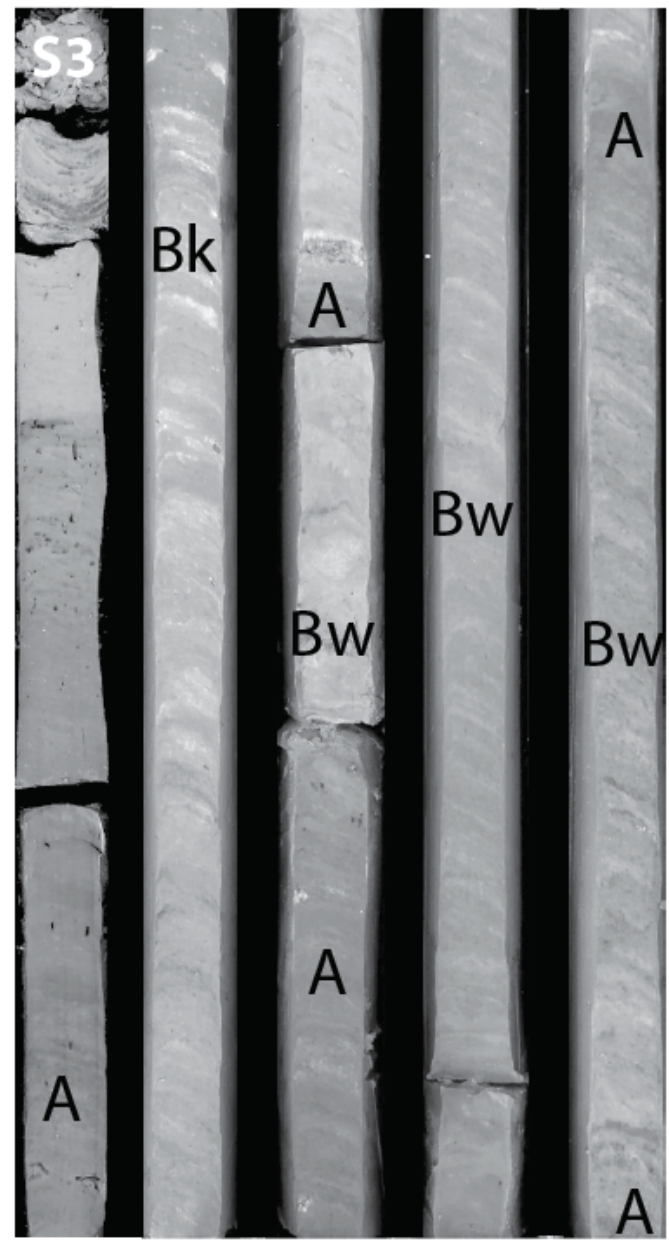

Figure 3. Representative core photographs of the paleosols (Younger Dryas [YD], Last Glacial Maximum [LGM], and marine oxygen isotope stage [MIS] 3) used in this study as prominent marker beds (from reference cores EM S3 and S15). Paleosol YD has single soil profile, whereas paleosols LGM and MIS 3 have a cumulative soil profile, consisting of vertically stacked, weakly developed paleosols. Core section is $1 \mathrm{~m}$ long.

Soil-forming processes are specific to a particular site, and several factors, including local topography, hydrology, vegetation, parent material, waterlogging, fluctuations of the water table, and local deposition rates may influence the rate of soil formation, thus leading to significant lateral changes in soil properties (Kraus, 1999; Retallack, 2012; McCarthy and Plint, 2013; Hartley et al., 2013; Rosenau et al., 2013). In order to prevent stratigraphic correlations from being affected by lateral variation of paleosol characteristics across single buried surfaces, we used the stratigraphic position of paleosols, more than soil properties, as a key to the characterization of paleosol-bounded packages.

Paleosols examined in core were mostly developed within massive clay, and occasionally silt overbank deposits. These paleosols are in general 1-2 $\mathrm{m}$ thick, being typified by upper dark-brownish, organic-rich horizons showing no reaction to $10 \% \mathrm{HCl}$, with a transition to underlying grayish horizons very rich in carbonate concretions (Fig. 3). These latter horizons commonly display yellow-brownish mottled colors due to the presence of $\mathrm{Fe}$ and Mn oxides, and they show strong reaction to $10 \% \mathrm{HCl}$. The dark horizons reflect the accumulation of organic matter and the leaching of calcium carbonate in the topsoil, and they are inferred to represent "A" horizons. The underlying clays display pedogenic calcium carbonate nodules and are likely the product of fluctuating redox conditions with iron dissolution and redeposition (i.e., Bk horizons). As with the physical description of the core samples, $\mathrm{Fe}$ and Mn oxides, as well as calcium carbonate accumulations, are common in the thin sections. Initial micromorphological analysis found no depositional fabric/relic bedding in the A or B paleosol horizons. Occasional weak clay alignment was observed in some of the samples, but the majority of the samples displayed an asepicplasmic fabric in the soil matrix. Abundant root fragments, preserved organic matter, and weak mottling were the most common pedogenic features observed. These features are characteristic of weakly developed paleosols (Inceptisols of Soil Survey Staff, 1999), which mark shortlived phases of subaerial exposure, on the order of a few thousand years (Retallack, 2001; Buol et al., 2011).

Coeval Inceptisols from the Bologna interfluve, at the basin margin (Fig. 1), have been shown to span intervals of $\sim 3000-4000 \mathrm{yr}$ (Amorosi et al., 2014) and are typically arranged in thin, paleosol-bounded overbank sequences. The paleosols used here for stratigraphic cor- 
Facies association

\begin{tabular}{|c|}
\hline Anthropogenic \\
\hline Floodplain \\
\hline Crevasse splay \\
\hline Swamp \\
\hline Crevasse channel \\
\hline Swamp \\
\hline Poorly drained floodplain \\
\hline Floodplain \\
\hline Fluvial channel \\
\hline
\end{tabular}
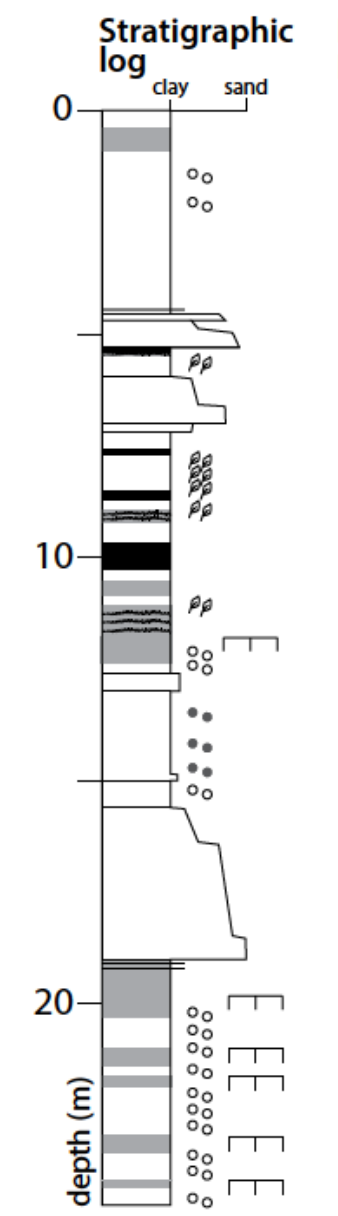

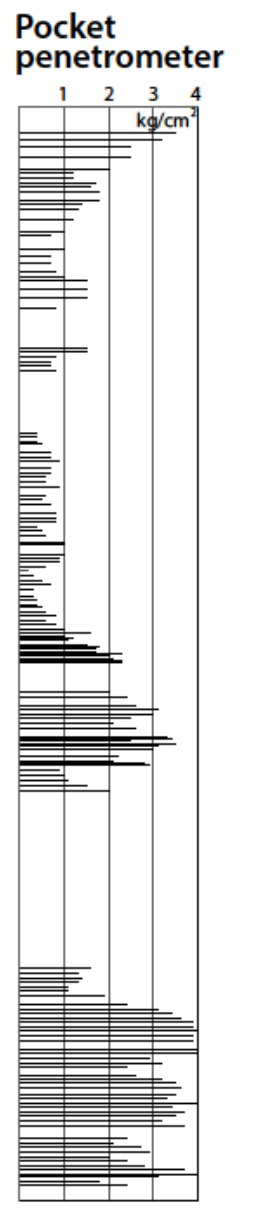

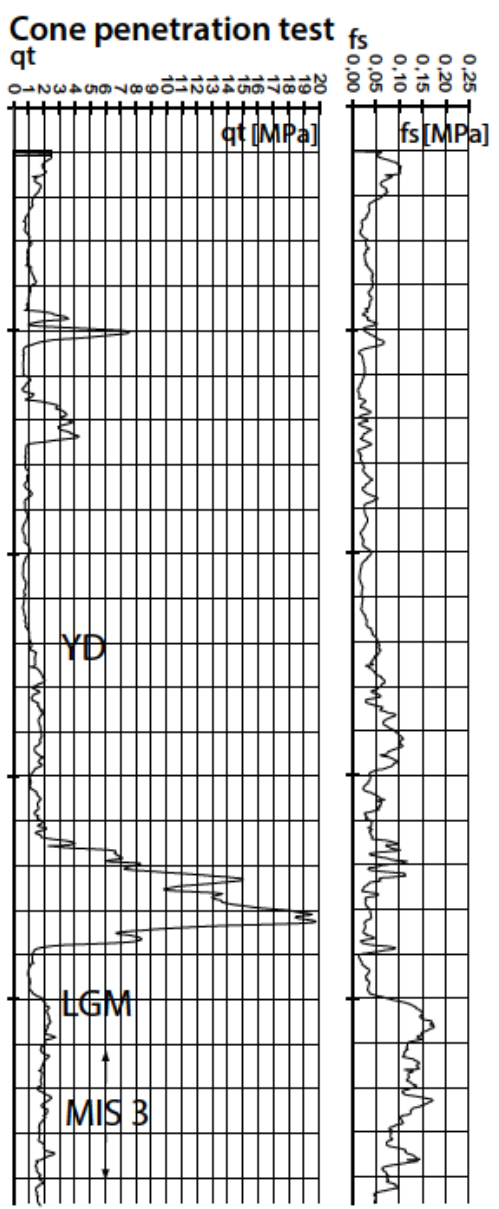

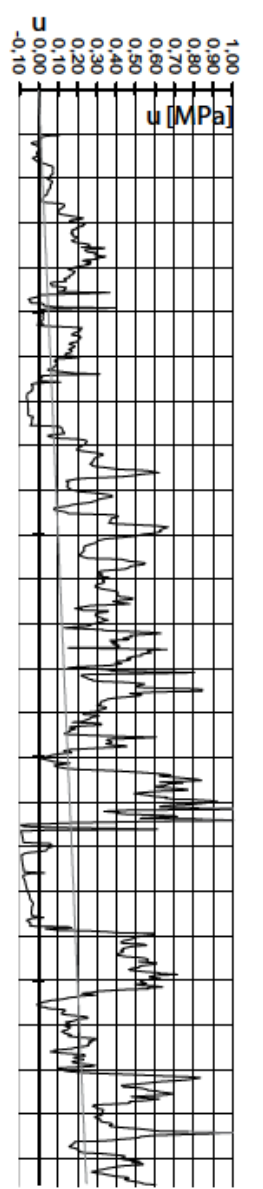

friction ratio

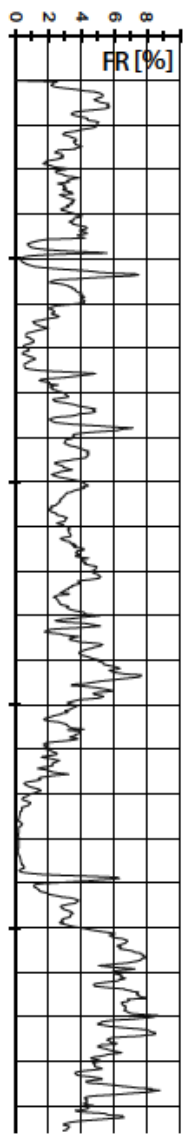

Organic-rich layer Peat Peaty clay $\sqcap \sqcap$ Paleosol $\rho_{\rho}$ Plant fragments ○ Iron oxides

Figure 4. Example of stratigraphic log/(piezo)cone penetration tests (CPTU) test calibration from core EM S3, showing the characteristic geotechnical signature of paleosols. Where paleosols have a cumulative soil profile, diagnostic changes in pocket penetration values and in CPTU parameters ( $q$-cone resistance, $f s$-sleeve friction, and $u$-pore pressure) are best observed at the very top of the pedogenically modified interval (Last Glacial Maximum ["LGM"]). YD-Younger Dryas paleosol, MIS 3-marine (oxygen) isotope stage 3 paleosols.

relation (Fig. 3) display the same characteristics as the coeval paleosols described at the basin margin and are assigned to the onset of the Younger Dryas (YD), to the onset of the Last Glacial Maximum (LGM), and to marine oxygen isotope stage 3 (MIS 3), respectively (see following). YD paleosols show a typical single profile, whereas LGM and MIS 3 paleosols have a cumulative soil profile, consisting of a set of vertically stacked, weakly developed paleosols (Fig. 3).

Previous work has shown that integration of geotechnical data with accurate facies analysis can be effective in delineating subsurface stratigraphy of unconsolidated deposits. A methodology for estimating facies characteristics from CPTU was developed by Amorosi and Marchi (1999), who demonstrated that individual facies associations bear unique and consistent compo- sitional and engineering properties. The same technique was subsequently applied by Lafuerza et al. (2005), Choi and Kim (2006), Sarti et al. (2012), and Styllas (2014), proving to be useful for the high-resolution sequence-stratigraphic analysis and three-dimensional reconstruction of alluvial to coastal successions.

In this study, we used the diagnostic signature of CPTU tests and PP profiles for paleosol identification following calibration with core data (Fig. 4). The key geotechnical features used to infer paleosols from CPTU tests included: (1) a subtle, but consistent increase in cone resistance $\left(q_{t}\right)$ with depth, (2) a sharp peak in the sleeve friction $f_{s}$ (friction of the sediment along the sleeve of the tool), recording the sharp contrast between normally consolidated floodplain facies and underlying, stiff pedogenically modified deposits (paleosols), and (3) an abrupt decrease in pore pressure, with $u<u_{0}$, where $u_{0}$ is the static equilibrium pore pressure (Fig. 4).

Engineering properties commonly reported by geotechnical data sheets, such as simple lists of PP values, may represent an additional, powerful tool for paleosol characterization (Amorosi et al., 2015). In particular, PP resistance can be extracted from routine core descriptions and may provide objective information on sedimentological characteristics not recognized at the time of core description. Pedogenically modified muds are commonly distinguished by their compressive strength, which is commonly two times higher than that recorded from overlying or underlying floodplain deposits (Fig. 4). Diagnostic compressive strength values for paleosols were observed to vary between 2.5 and 3.5 $\mathrm{kg} / \mathrm{cm}^{2}$ in the A horizon, and between 3.0 and $4.5 \mathrm{~kg} / \mathrm{cm}^{2}$ in the underlying Bk horizon (Fig. 3). 

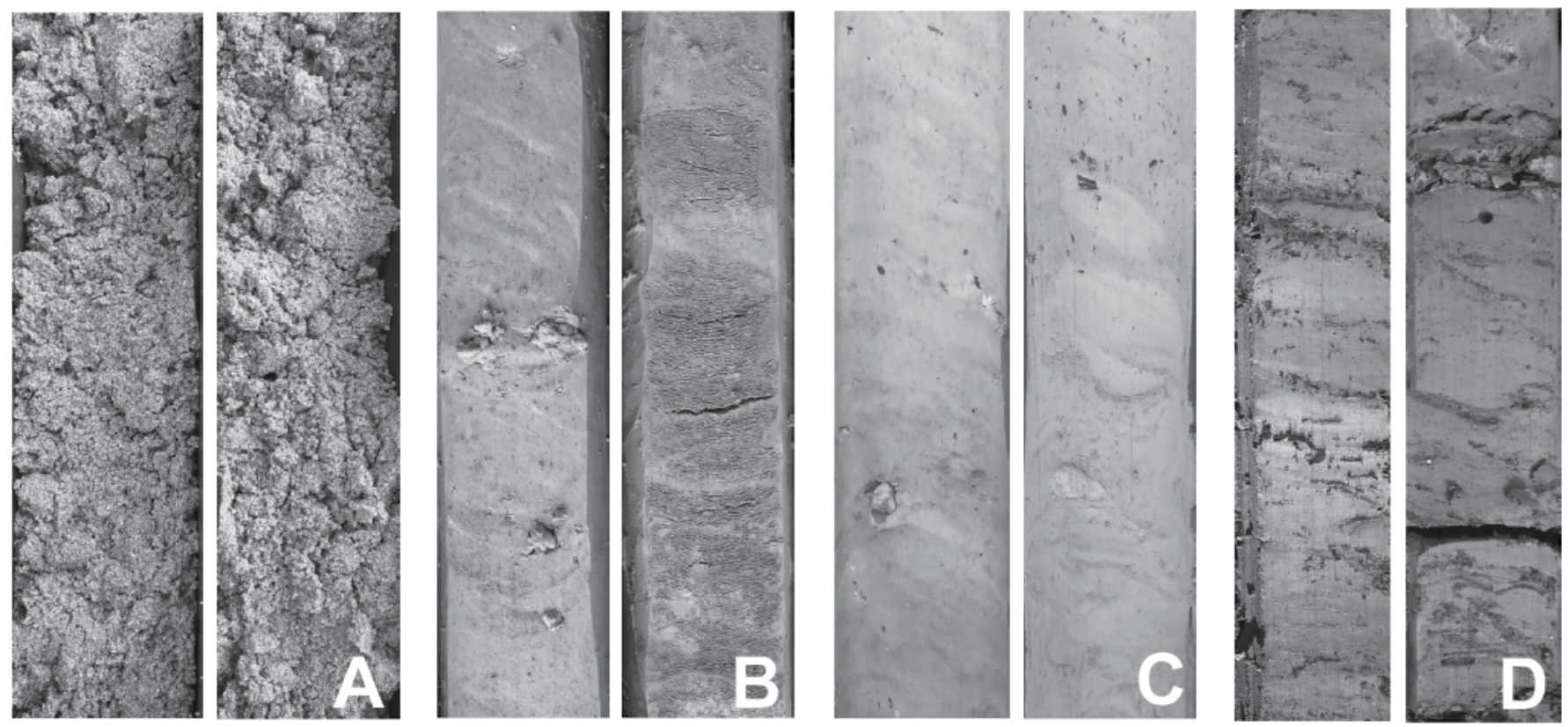

Figure 5. Representative core photographs of the major facies associations discussed in text. (A) Fluvial channel sands from core EM S2, (B) well-drained floodplain silts and clays (left) and levee silt/sand alternations (right) from core EM S3, (C) poorly drained floodplain clays and silts from core EM S6, and (D) inner estuary/swamp clays from cores EM S3 (left) and EM S6 (right). Core bottom is lower-left corner. Core section is $\mathbf{4 0} \mathrm{cm}$ long.

\section{SEDIMENTARY FACIES}

This part of the study involved detailed core analysis, integrated with available stratigraphic descriptions, and sedimentological interpretation of CPTU and PP tests. Six facies associations were identified in the cores (Fig. 5). In general, fluvial to inner estuarine (coastal swamp) facies associations are dominant beneath the modern alluvial plain (Fig. 2). These lithofacies represent the proximal equivalents of the outer estuarine, coastal, and shallow-marine depositional settings documented at length at more distal locations (Amorosi et al., 1999, 2003, 2005, 2008; Fig. 2 herein). The specific characteristics of each facies are shown in Table 1.

\section{Cross-Bedded Coarse to Medium Sand (Fluvial-Channel Deposits)}

\section{Description}

This facies association consists of coarse to medium sand bodies (Fig. 5A), up to $10 \mathrm{~m}$ thick, with fining-upward tendency, and silty sand at the top. In the north, below the modern Po River, sand bodies are vertically stacked, forming amalgamated complexes up to $40 \mathrm{~m}$ thick. These bodies are characterized by erosional lower boundaries, while the upper contacts to the overlying muds are either sharp or transitional. Where preserved, sedimentary structures include unidirectional, high-angle cross- stratification and subhorizontal bedding. Wood fragments are common accessory materials that characterize the lower portion of this unit. No invertebrate fossils were found within this facies association. Sand bodies show a diagnostic CPTU signature, with high cone tip resistance values $\left(3<q_{t}<20 \mathrm{MPa}\right)$ that decrease upward, and negative pore pressure $(u<0)$.

\section{Interpretation}

The main characteristics of this facies association, i.e., lithology, erosional lower boundary, thickness, sedimentary structures, and accessory materials, contribute to its interpretation as fluvial-channel deposits. This interpretation is supported by the presence of unidirectional flow structures, and by the characteristic finingupward tendency, resulting from core and CPTU tests. The low pore-water pressure reported by the CTPU test indicates high permeability and a tendency to dilate. The sharp or transitional upper boundaries to the overlying mud reflect abrupt or gradual channel abandonment, respectively.

\section{Cross-Bedded Medium Sand to Silt (Crevasse and Levee Deposits)}

\section{Description}

With a thickness in the range of $0.2-2 \mathrm{~m}$, this facies association includes two facies. Facies 1 consists of medium to very fine sand with sub- ordinate silt. Sand bodies show either finingupward trends with erosional lower boundaries or coarsening-upward tendency and sharp tops. These sand bodies have lower cone tip resistance $\left(3<q_{t}<10 \mathrm{MPa}\right)$ than fluvial-channel sands, along with lower pore-water pressure $(u \leq 0)$. Facies 2 shows the rhythmical alternation of fine sand, silt, and clay on a scale of a few millimeters to centimeters (Fig. 5B). Sands generally display sharp lower boundaries and fining-upward tendencies, with sharp or gradational sand-to-mud contacts. Cone tip resistance values $\left(q_{t}\right)$ are in the range of 3-8 $\mathrm{MPa}$, with pore pressure values generally $\gg u_{0}$ in clays, and $u<u_{o}$ (and locally $u<0$ ) in silts and sands. Compressive strength values derived from PP tests measured on clay intervals are $<2.5 \mathrm{~kg} / \mathrm{cm}^{2}$. The main sedimentary structures are horizontal lamination and small-scale cross-lamination. No invertebrate fossils were found (Table 1).

\section{Interpretation}

This facies association is related to two major subenvironments close to the river channel. Higher sand/mud ratios are interpreted to reflect proximity to fluvial channels, while lower ratios indicate increasing distance from the channel axis. Medium to fine sand bodies with fining-upward trend and erosional bases (facies 1) are interpreted as crevasse channels. This facies differs from its fluvial counterpart by the lower thickness and finer grain size, both 
TABLE 1. SUMMARY CHART OF THE VARIOUS FACIES ASSOCIATIONS IDENTIFIED IN THIS WORK

\begin{tabular}{|c|c|c|c|c|c|c|c|c|}
\hline Facies association & Lithology & Color & Sedimentary features & $\begin{array}{l}\text { Accessory } \\
\text { material }\end{array}$ & $\begin{array}{l}\text { PP values } \\
\left(\mathrm{kg} / \mathrm{cm}^{2}\right)\end{array}$ & $q_{t}(\mathrm{MPa})$ & $f_{s}(\mathrm{MPa})$ & $u$ \\
\hline Fluvial channel & $\begin{array}{l}\text { Coarse to } \\
\text { fine sand }\end{array}$ & Yellow to gray & $\begin{array}{l}\text { Sharp base, sharp or gradational top, } \\
\text { fining-upward trend, cross-lamination, } \\
\text { flat lamination }\end{array}$ & $\begin{array}{l}\text { Wood fragments, } \\
\text { no invertebrate fossils }\end{array}$ & & $3-20$ & $0.02-0.1$ & $<0$ \\
\hline $\begin{array}{l}\text { Crevasse channel } \\
\text { and splay }\end{array}$ & $\begin{array}{l}\text { Medium to } \\
\text { very fine sand }\end{array}$ & Yellow to gray & $\begin{array}{l}\text { Sharp base and top, fining-upward trend } \\
\text { (channel), gradational base, sharp top, } \\
\text { coarsening-upward trend (splay) }\end{array}$ & $\begin{array}{l}\text { Wood fragments, } \\
\text { no invertebrate fossils }\end{array}$ & & $3-10$ & $\approx 0.05$ & $\leq u_{0},<0$ \\
\hline Levee & $\begin{array}{l}\text { Silty sand, } \\
\text { silt, and clay }\end{array}$ & Yellow to gray & Silt-sand/clay-silt alternations & Bioturbation & & $3-8$ & $\approx 0.05$ & $\gg u_{0},<u_{0}$ \\
\hline $\begin{array}{l}\text { Well-drained } \\
\text { floodplain }\end{array}$ & Silt and clay & Yellow to gray & $\begin{array}{l}\text { No grain-size trend, subtle lamination, } \\
\text { mottles }\end{array}$ & $\begin{array}{l}\text { Bioturbation, roots, } \\
\text { and plant fragments }\end{array}$ & $1.8-2.5$ & $1.2-2.5$ & $0.02-0.05$ & $>u_{0}$ \\
\hline Paleosol & Silt and clay & Black to gray & $\begin{array}{l}\text { Very stiff, dark A horizon, carbonate-rich } \\
\text { Bk horizon }\end{array}$ & $\begin{array}{l}\text { Organic matter, } \\
\text { carbonate concretions }\end{array}$ & $2.5-4.5$ & $2-4$ & $0.05-0.20$ & $<u_{0}$ \\
\hline $\begin{array}{l}\text { Poorly drained } \\
\text { floodplain }\end{array}$ & Clay and silt & $\begin{array}{l}\text { Gray to } \\
\text { dark gray }\end{array}$ & No grain-size trend, subtle lamination & Organic matter & $1.2-1.8$ & $0.8-1.2$ & $0.02-0.05$ & $>>u_{0}$ \\
\hline $\begin{array}{l}\text { Inner estuary/ } \\
\text { coastal swamp }\end{array}$ & Clay & $\begin{array}{l}\text { Dark gray } \\
\text { to black }\end{array}$ & No grain-size trend, subtle lamination & $\begin{array}{l}\text { Peat, wood, and } \\
\text { plant fragments, } \\
\text { freshwater fossils }\end{array}$ & $<1.2$ & $0.1-0.8$ & $<0.05$ & $>u_{0}$ \\
\hline $\begin{array}{l}\text { Outer estuary/ } \\
\text { lagoon }\end{array}$ & Clay & $\begin{array}{l}\text { Gray to } \\
\text { dark gray }\end{array}$ & $\begin{array}{l}\text { No grain-size trend, subtle lamination, } \\
\text { sand intercalations }\end{array}$ & $\begin{array}{l}\text { Rare plant fragments, } \\
\text { brackish fossils }\end{array}$ & $<1.2$ & $0.1-0.8$ & $<0.05$ & $>>u_{0},<0$ \\
\hline
\end{tabular}

clearly shown by CPTU parameters. Silty sand to fine sand, coarsening-upward deposits with gradational lower boundaries and sharp tops, on the other hand, are inferred to represent splay deposits. Heterolithic sand-silt layers (facies 2), reflecting traction plus fallout deposition, are interpreted as proximal levee deposits, while silt-clay couplets are interpreted to be distal levee facies.

\section{Bioturbated and Oxidized Silt and Clay (Well-Drained Floodplain Deposits)}

\section{Description}

This facies association is characterized by a succession of thoroughly bioturbated and mottled silts and clays, up to several tens of meters thick. Carbonate nodules, roots, and plant fragments are common accessory materials. Sedimentary structures are rare and include faint horizontal lamination. Yellow to brown clay variegation due to $\mathrm{Fe}$ and $\mathrm{Mn}$ oxides is very common (Fig. 5B). Intercalated with this muddy succession, there are thin layers of very fine sand with sharp base. Weakly developed paleosols are commonly intercalated with this facies association. Compressive strength values from PP tests are commonly in the range of 1.8 and $2.5 \mathrm{~kg} / \mathrm{cm}^{2}$, and cone tip resistance values $\left(q_{t}\right)$ from CPTU tests are narrowly constrained between 1.2 and 2.5 MPa. Pore-water pressure values are $>>u_{0}$ (Table 1$)$.

\section{Interpretation}

Bioturbated and oxidized mud commonly associated with pedogenically modified horizons is interpreted to reflect deposition in low-energy freshwater environments, prone to subaerial exposure, such as well-drained flood- plains. Thin sandy layers are identified as distal fringes of crevasse splays or levees. Compressive strength and cone tip resistance values are typical for floodplain sediments (Amorosi and Marchi, 1999; Sarti et al., 2012). Pore pressure shows positive values due to the presence of massive clay, which represents a barrier to fluid circulation.

\section{Homogeneous Gray Clay to Silty Clay (Poorly Drained Floodplain Deposits)}

\section{Description}

This facies association, generally $<5 \mathrm{~m}$ thick, consists of bioturbated, gray to dark-gray clay and silty clay deposits, with faint horizontal lamination, abundant organic matter, and sparse carbonate nodules (Fig. 5C). Plant fragments are also common. Compared to the well-drained floodplain facies association, this muddy deposit is softer, has homogeneous color, has a higher clay proportion, and typically lacks paleosols and Fe-Mn oxides. Cone resistance values from CPTU generally range between 0.8 and $1.2 \mathrm{MPa}$, with pore pressure typically $>>u_{0}$, while the compressive strength registered from $\mathrm{PP}$ varies between 1.2 and $1.8 \mathrm{~kg} / \mathrm{cm}^{2}$ (Table 1 ).

\section{Interpretation}

The absence of soil features and the variegated colors suggest that deposition of this facies association took place in a low-energy, low-elevation topographic setting with occasional subaerial exposure, probably under conditions of high water table. Carbonate nodules were likely formed through evaporation of groundwater, at or above the water table. This facies association is likely to represent a poorly drained floodplain, at the transition between well-drained and almost permanently submerged environments. CPTU tests and PP values also record intermediate values between subaerially exposed floodplain deposits and swamp facies (Table 1).

\section{Organic-Matter-Rich Clay and Peat (Inner-Estuary and Coastal- Swamp Deposits)}

\section{Description}

This facies association, up to $15 \mathrm{~m}$ thick, has a characteristic wedge-shaped geometry and includes a succession of bioturbated, dark-gray to black, very soft clays with subordinate silts and sandy silts. Undecomposed organic matter, such as plant fragments, wood, root traces, and peat layers up to $0.5 \mathrm{~m}$ thick, is commonly encountered (Fig. 5D). Thin sand layers with a fining-upward tendency and sharp base display flat lamination. This facies association is typified by a lack of Fe and Mn oxides. Freshwater ostracods, such as Candona spp., are commonly encountered. CPTU tests show a linear cone response, invariably below $0.8 \mathrm{MPa}$. Pore pressure increases linearly with the depth, reflecting a uniform lithology. Small peaks in cone resistance are generally associated with higher peaks in sleeve friction, in pore pressure, and in the friction ratio $\left(\mathrm{FR}=f_{\mathrm{s}} / q_{\mathrm{t}}\right)$ column. Pocket penetrometer values are almost invariably lower than $1.2 \mathrm{~kg} / \mathrm{cm}^{2}$ (Table 1).

\section{Interpretation}

Dark-gray clay associated with abundant peat, undecomposed organic matter, and freshwater fossils, coupled with a lack of oxide variegation, is inferred to represent deposition in topographically depressed interfluvial areas 
with stagnant waters, high organic content, and reducing conditions, such as coastal swamp environments. Thick peat layers, wood residues, and root traces are interpreted to represent organic soils (Histosols). The remarkable thickness and lateral extent of this facies association suggest persistent stagnant conditions in the inner portion of an estuary. Very low cone resistance and the linear response are consistent with undrained conditions and submergence. The long time required to dissipate excess pore pressure $(u)$ indicates very low permeability. Concurrent peaks in $q_{p} f_{s}, u$, and FR have been inferred to represent the CPTU response to peat layers. Horizontal lamination is interpreted as the result of occasional flood events that deposited silt to sand layers.

\section{Mollusk-Rich Clay with Sand Intercalations (Outer-Estuary and Lagoonal Deposits)}

\section{Description}

This facies association, generally less than $5 \mathrm{~m}$ thick in the study area, is composed of a succession of soft, homogeneous gray clay and silty clay with rare sand intercalations, a few centimeters to a few decimeters thick. Plant and wood fragments are only occasionally encountered. These deposits are rich in mollusk bivalves, with local abundance of Cerastoderma glaucum shells. Seaward, sand alternations are thicker and more abundant. Sand layers are characterized by sharp lower and upper bound- aries and fining-upward internal trends. Cone resistance values show a linear response, with an increase in pore pressure with depth. PP tests show compressive strength values lower than $1.2 \mathrm{~kg} / \mathrm{cm}^{2}$.

\section{Interpretation}

Soft clays with local abundance of Cerastoderma glaucum, a typical brackish water bivalve, are inferred to have been deposited in a barred environment partly connected to the open sea, such as a lagoon or an outer estuary. The seaward increase in the sand-to-mud ratio reflects increasing marine (storm and tidal) influence. On CPTU profiles, this facies association is very similar to the inner estuarine deposits. PP values from this facies association are also very similar to those of paludal deposits and cannot be used to distinguish brackish from freshwater paleoenvironments.

\section{PALEOSOL STRATIGRAPHY AND ASSOCIATED FLUVIAL BODIES}

A high-resolution stratigraphic investigation of the subsurface in the southern Po Plain was conducted through the construction of stratigraphic panels (Figs. 6-9). To this purpose, we selected four transects with SW-NE orientation, from the basin margin to the Po channel belt (Fig. 1). As the overall quality of stratigraphic resolution declines with depth, reliable correlations were obtained from the uppermost $40 \mathrm{~m}$, where well density and radiocarbon dating were sufficient to generate refined stratigraphic reconstructions.

Taken together, all stratigraphic panels portray a consistent stratigraphic architecture of the alluvial system along a series of margin-toaxis transects (Figs. 6-9). Regionally extensive, pedogenically modified surfaces (and related paleosol-bounded, overbank cycles) are the dominant stratigraphic marker to the SW, while a complex set of multilateral and multistory sand bodies with diagnostic pinch-out in a SW direction is invariably observed downdip. For this paper, we focused on the stratigraphic reconstruction of the axial (Po River) flow, which is directed subparallel to the Apennine thrust front (see the southern margin of the Po channel belt in Fig. 1). Transverse (Apennine) flow, although an important component of the drainage system, is deliberately not covered in this paper, and the four cross sections of Figures 6-9 largely run along the narrow, undissected region between adjacent Apennine river systems.

Overall, the composite fluvial-channel system fed by the Po River comprises up to $40 \mathrm{~m}$ of sand-dominated strata, with thin mud intercalations (Fig. 7). The individual channel belts are commonly amalgamated, yet the presence of distinct layers of Pleistocene fluvial sands, each eroded into the underlying one and locally separated by thin muddy intervals, denotes multiple cycles of erosion and deposition (Figs. 6 and 7). Fluvial deposits become progressively thinner toward the SW, where sand bodies are replaced by laterally extensive paleosols.

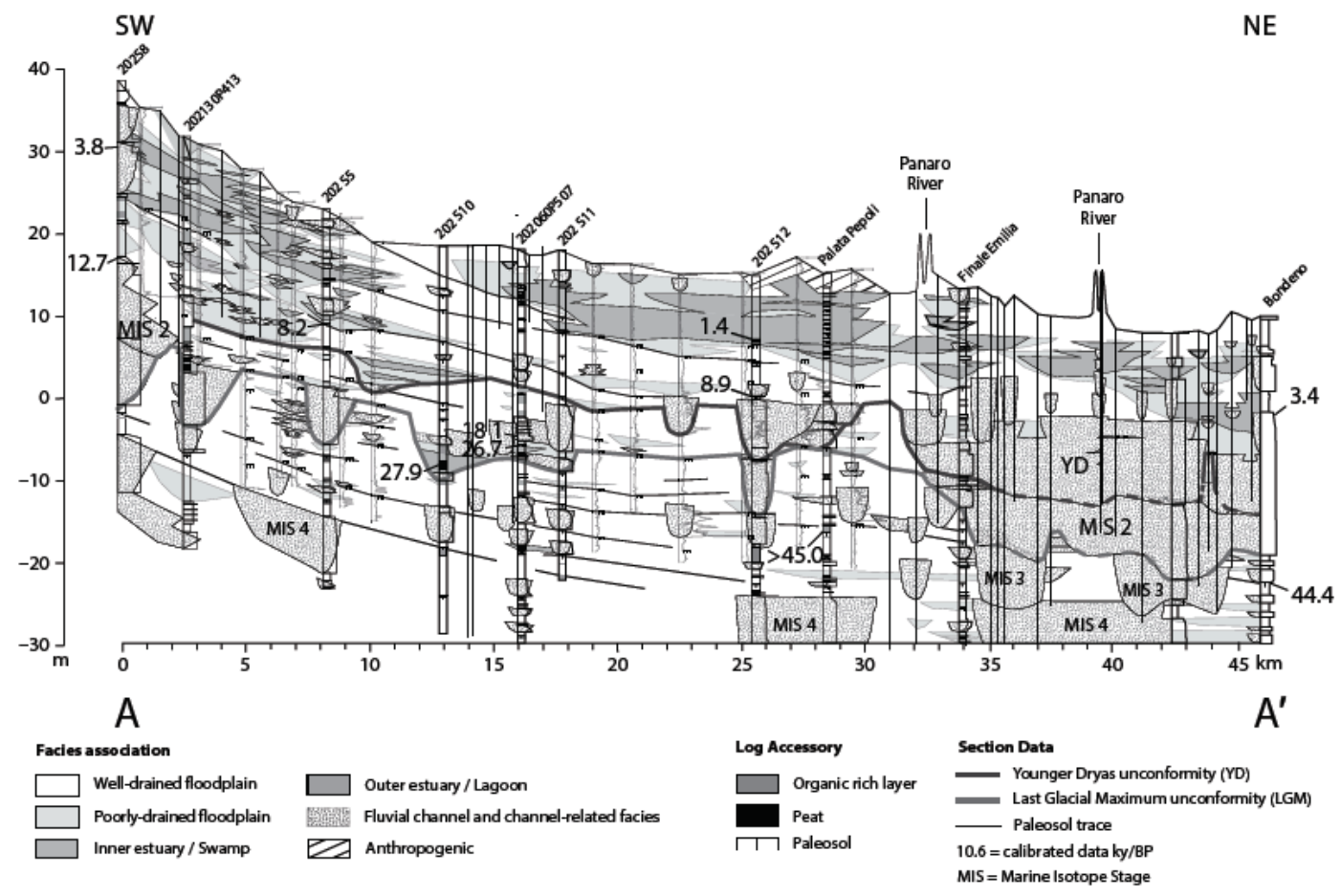

Figure 6. SW-NE cross-section A-A' depicting stratigraphic relationships of paleosols and channel-belt sand bodies from the central Po Plain (for location, see Fig. 1). Thick mediumgray line corresponds to the paleosol and to the base of channel belts formed during the marine (oxygen) isotope stage (MIS) 3-2 glacial period relative sea-level fall (Last Glacial Maximum [LGM]), whereas thick black line represents paleosol and base of the channel belt that formed in response to the Younger Dryas cold event. ' 0 ' is the present sea level. 


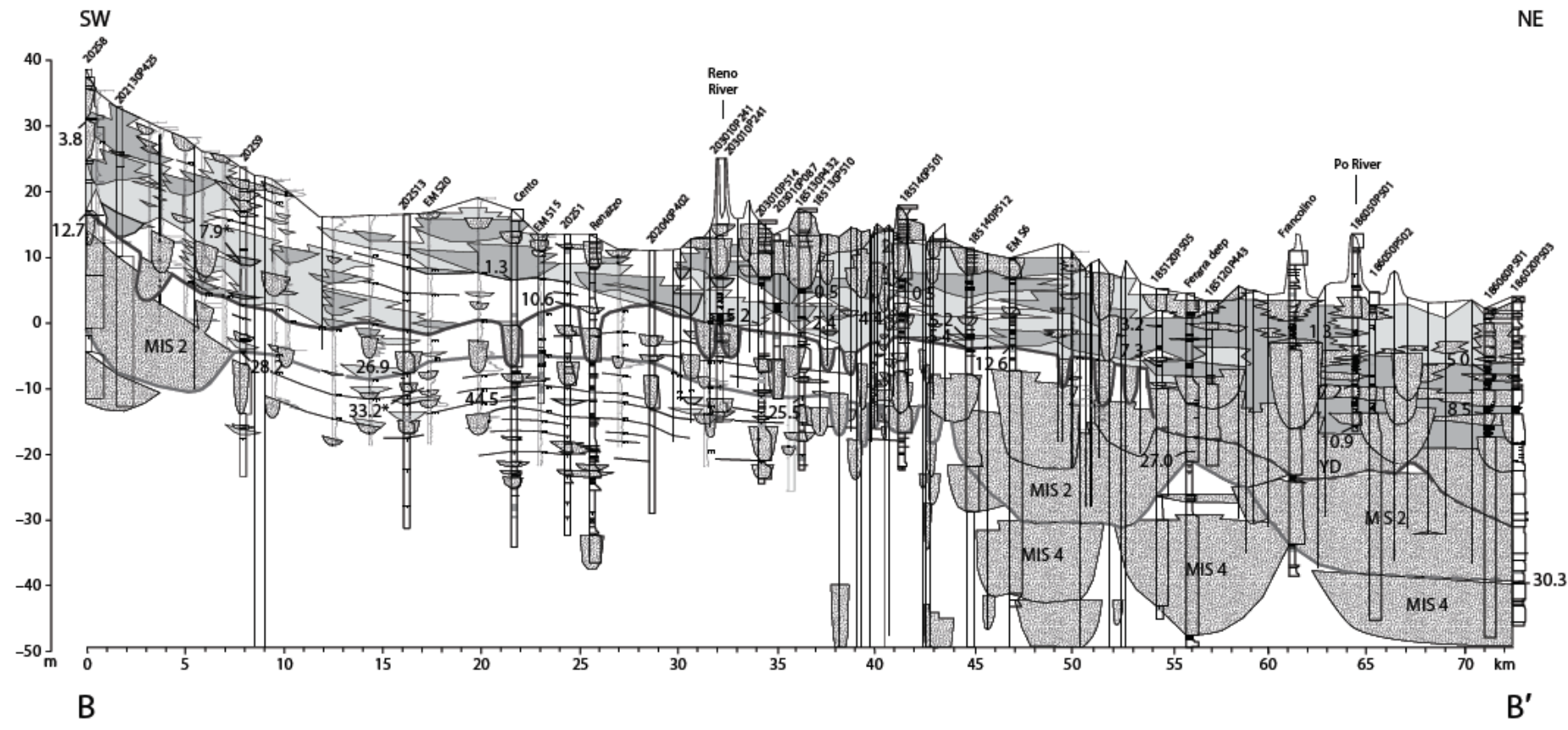

Figure 7. SW-NE cross-section B-B' depicting stratigraphic relationships of paleosols and channel-belt sand bodies from the Ferrara area (Fig. 1). Note paleosol deformation in response to active tectonics. MIS-marine (oxygen) isotope stage. Symbols are as in Figure 6.

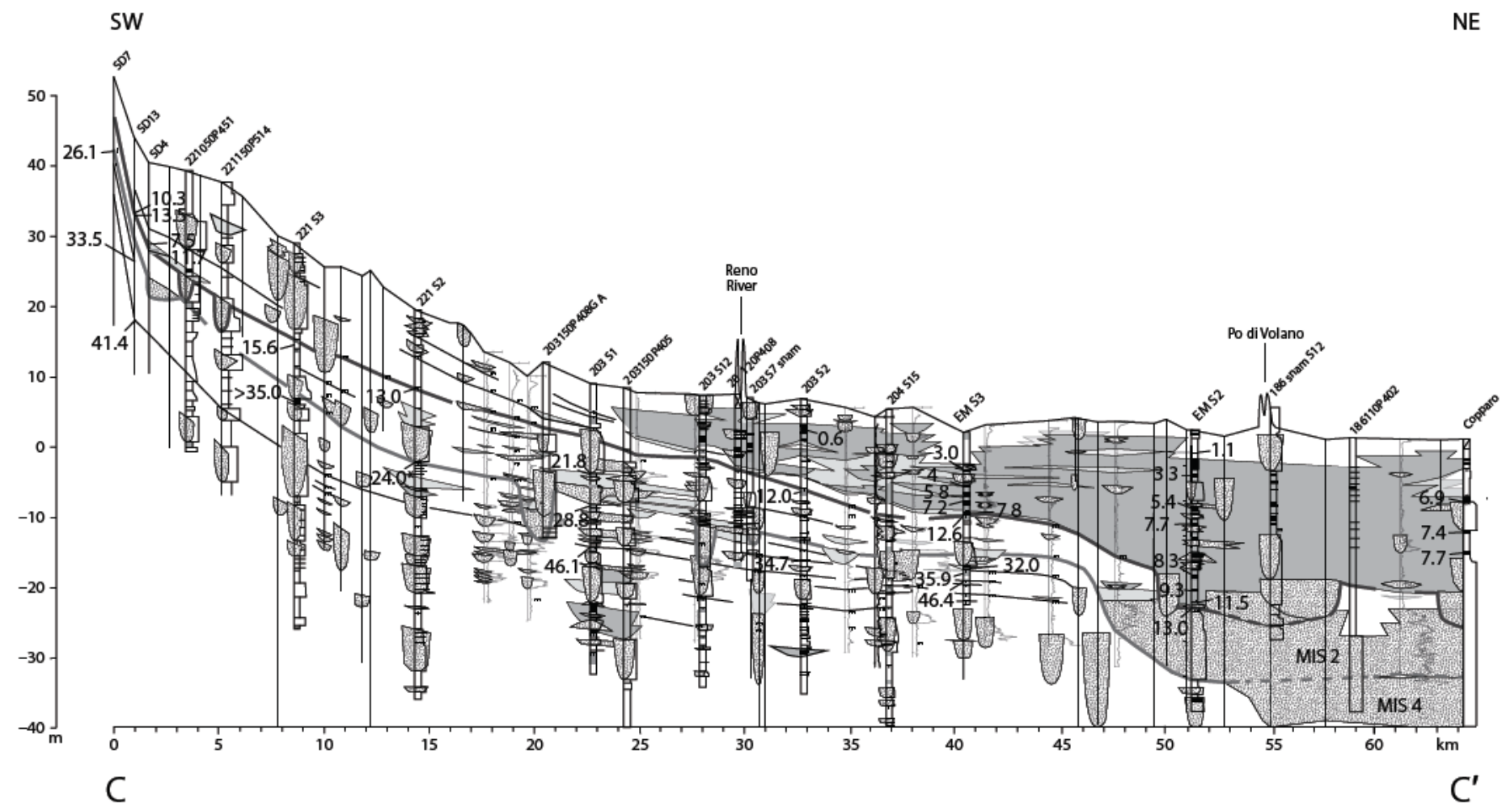

Figure 8. SW-NE cross-section $\mathrm{C}^{-\mathrm{C}^{\prime}}$ depicting stratigraphic relationships of paleosols and channel-belt sand bodies from the Bologna area (Fig. 1). The Last Glacial Maximum (LGM) and Younger Dryas (YD) paleosols recently identified at the basin margin (Amorosi et al., 2014) can be traced basinwide, almost continuously from the Apennines to the Po River. MIS-marine (oxygen) isotope stage. Symbols as in Figure 6. 


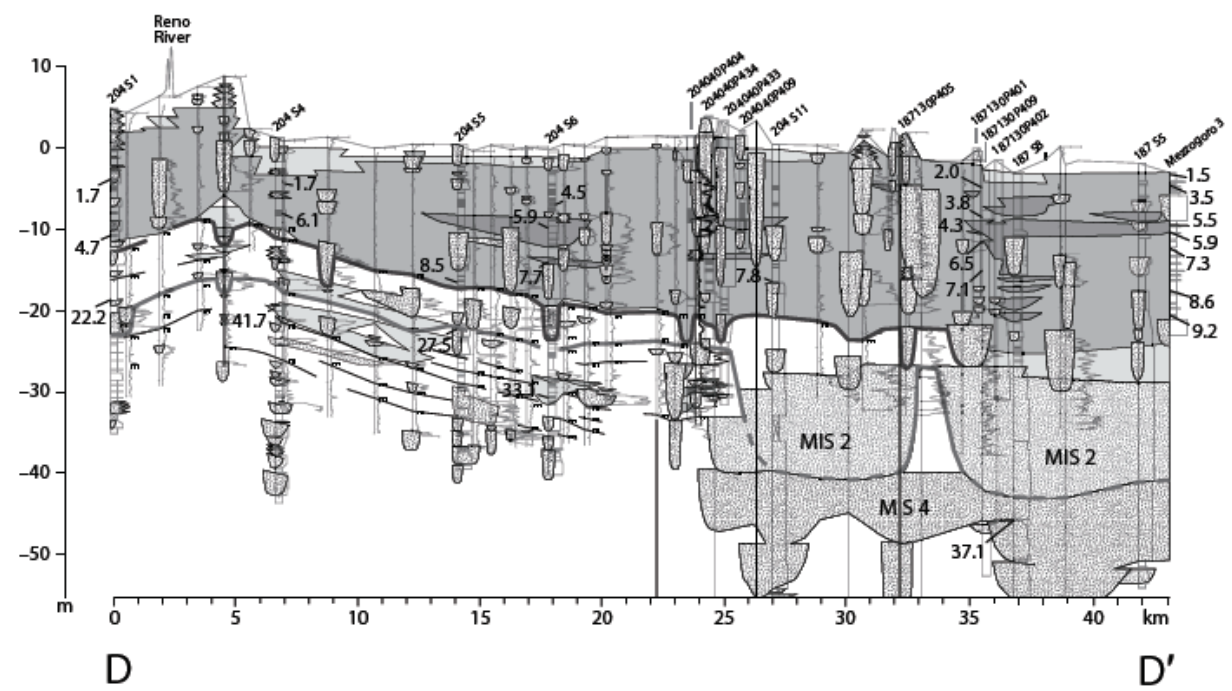

Figure 9. SW-NE cross-section D-D' depicting stratigraphic relationships of paleosols and channel-belt sand bodies close to the modern coastal plain. Note that the Holocene succession above Younger Dryas (YD) paleosol is entirely represented by estuarine deposits. MIS-marine (oxygen) isotope stage. Symbols as in Figure 6.

Owing to relatively low data density, the detailed paleosol-to-channel-belt transitions and stratal relationships at the southern edge of the channel-belt systems may locally remain somewhat cryptic.

A precise chronostratigraphic framework for the erosionally based, channel-belt units is lacking. Based on sparse radiocarbon dates from the intervening muddy intervals, the lower laterally extensive layers appear to be older than $40 \mathrm{ka}$ (Figs. 6 and 9). Based on these data and on pollen profiles from correlative sections (Amorosi et al., 2004, 2008), we tentatively assign these sand bodies to MIS 4 and MIS 3 (Figs. 6-9). Up section, a well-developed channel-belt sand body dated between ca. 30 and $20 \mathrm{ka}$ is assigned to MIS 2. The youngest channel-belt unit is less laterally extensive (Figs. 7-9) and narrowly constrained in age between ca. 12 and 9 ka (Figs. 6-8).

South of the modern Po channel belt, paleosols can be traced through much of the Po Plain, up to the basin margin, over distances in excess of $40 \mathrm{~km}$ (Figs. 6-8). Though we did not perform detailed paleosol characterization through geochemical and micromorphological analyses, the apparently weakly developed character of all late Pleistocene paleosols over the whole study area (Inceptisols) suggests persistence of broadly similar soil-forming conditions as the entire soil sequence developed (Retallack, 1983).

Poor paleosol maturity reflects cessation of deposition for only a few thousand years (Retal- lack, 2012), which is confirmed by the narrow range of radiometric dates obtained from individual paleosols. Pedogenesis acted over short intervals of time between successive flooding events. The apparently unweathered interfluve succession includes overbank fines and heterolithic facies, inferred to represent crevasse and levee deposits, with only minor fluvial-channel sand bodies (Figs. 6-9).

In general, it is considerably more difficult to correlate the older paleosols, because they are penetrated by few cores and are beyond the ${ }^{14} \mathrm{C}$ dating limit. In these instances, stratigraphic correlations were carried out exclusively on the basis of geometric criteria. In contrast, owing to their occurrence in the time window of radiocarbon dating and their widespread stratigraphic record in shallow boreholes, paleosols younger than $40 \mathrm{ka}$ can be traced throughout the entire study area (Figs. 6-9).

Two prominent buried soils were identified in this work. The LGM paleosol, which caps a set of vertically stacked, weakly developed paleosols (Figs. 3 and 4), spans $\sim 5$ k.y. between ca. 29 and 24 ka (see seven ${ }^{14} \mathrm{C}$ dates in Figs. 7-9), thus corresponding with the onset of the LGM (i.e., the MIS 3-2 transition). In contrast, the hiatus associated with YD paleosol spans a significantly shorter time interval between 12.9 and $11.5 \mathrm{ka}$ (see seven ${ }^{14} \mathrm{C}$ dates in Figs. 6-8), which coincides with the YD cold event. The cumulative soil profile of the LGM paleosol (Fig. 3) suggests that soil-forming processes around the MIS 3-2 transition were repeatedly interrupted by alluviation, and that soils had relatively short time intervals in which to form (Flaig et al., 2013), implying continuous generation of accommodation. Based on a physical stratigraphic approach, the LGM paleosol represents the LGM (lowstand) exposure surface and is unequivocally identified on the combined basis of its composite nature and diagnostic stratigraphic position, correlative with a considerable number of fluvial sand bodies (MIS 2 Apennine channel-belt units in Figs. 6 and 7). On the other hand, the YD paleosol commonly separates alluvial Pleistocene deposits from overlying, poorly drained floodplain to estuarine Holocene facies (Figs. 7-9), and it represents the first basinwide paleosol encountered beneath the ground surface.

\section{PALEOVALLEY SYSTEMS VERSUS NONINCISED CHANNELS}

Sequence boundaries within nonmarine successions influenced by high-magnitude sea-level and climate fluctuations are typically recognized at the base of incised valley fills and in the associated interfluve paleosols (Van Wagoner et al., 1990; Gibling and Bird, 1994; Gibling and Wightman, 1994; Aitken and Flint, 1996; McCarthy and Plint, 1998; McCarthy et al., 1999; Plint et al., 2001). In these areas, the paleosolincised valley couplet forms the fundamental trait for reconstructing the stratigraphic architecture of fluvial deposits, and the sequence boundary is commonly highlighted by deeply weathered paleosols developed on interfluves. However, deep channel incision is not the only possible response of fluvial systems to falling base level or climate change: It has been documented that there is a complete gradation from nonincised channels, through shallowly incised systems, to very deeply entrenched valleys (Boyd et al., 2006; Gibling et al., 2011). Similarly, it has been shown that the soil-forming intervals bracketing the sequence boundary might consist of a complex series of vertically stacked, aggradational paleosols (McCarthy and Plint, 2013), i.e., soil zones (Morton and Suter, 1996), cumulative paleosols, or pedocomplexes (Kraus, 1999).

A similar conclusion emerges for the late Quaternary alluvial succession of the Po Plain: Here, the sediment record of paleosols and associated fluvial bodies is punctuated by a characteristic compound architecture made up of aggradationally stacked, channel-belt sand bodies (Blum et al., 2013) that correlate laterally to thin, essentially coeval, paleosol-bearing cycles (Amorosi et al., 2014). Most of these paleosolbounded depositional packages resemble the fluvial aggradational cycles of Atchley et al. (2013). Despite repeated periods of rapid fall 
in base level during the past 120 k.y., we found no subsurface evidence of deeply incised valley systems (for an example from the Gulf of Mexico, see Morton and Suter, 1996).

Miscorrelation between individual paleosols and related channel-belt sand bodies is possible, due to the (1) low density of stratigraphic data, (2) close stratigraphic spacing of paleosols, and (3) paucity of radiocarbon dates. In general, however, it can reasonably be assumed that channel-belt sand bodies comparable with the scale of individual layers $(<10 \mathrm{~m}$, such as in the case of the YD channel belt) indicate lateral migration in essentially nonincising river channels (Fig. 10). In contrast, wider and thicker (15$20 \mathrm{~m}$ ) sand bodies, such as the LGM channel belt (Fig. 10), are interpreted to reflect shallow river incision associated with low-relief incised valleys larger and deeper than a single channel (Dalrymple et al., 1994; Shanley and McCabe, 1994; Boyd et al., 2006; Gibling et al., 2011).

The lower bounding surface of the LGM channel belt, though smoothed (Holbrook, 2001; Wellner and Bartek, 2003), involves significant erosional truncation of the underlying strata (Figs. 6-10). Our view of the stratigraphic architecture implies that at the maximum extent of glaciation (MIS 3-2 transition), the Po River was confined within a shallow valley, which permitted more time for pedogenesis on the interfluves before the valley was filled. Consistent with this hypothesis, the LGM paleosol is more prominently developed than the YD paleosol (Fig. 3). Another potential candidate for a shallow incised-valley fill is the sand-dominated body tentatively assigned to the MIS 5-4 transition (Fig. 10). Unfortunately, we do not have sufficient stratigraphic data and chronologic constraints at this stage to corroborate our hypothesis.

\section{EXTERNAL CONTROLS ON ALLUVIAL ARCHITECTURE}

Fluvial systems may respond to a variety of allogenic controls, including eustasy, climate, tectonics, and basin subsidence. The relative impact of each of these factors in shaping alluvial architecture has been addressed by several models (Wright and Marriott, 1993; Shanley and McCabe, 1994). In the subsurface of the modern Po coastal plain, late Quaternary T-R cycles with periodicities of 100 k.y. (Milankovitch band) have been correlated with globally recognized sea-level events, highlighting the role of fluctuating base level as a primary control on sedimentation (Amorosi et al., 2004). Based on physical correlations with the adjacent coastal successions, corroborated by pollen data, eccentricity-driven depositional cycles have been traced inland, within entirely nonmarine deposits (Fig. 2). At these locations, thick, amalgamated sand-dominated intervals are thought to have been formed during glacial periods, while abrupt transitions to more isolated, ribbon-shaped fluvial bodies have been delineated as lateral equivalents of the transgressive surfaces (Amorosi et al., 2008).
Here, we assess a possible control on the stratigraphy by allogenic factors on a higherresolution (sub-Milankovitch) temporal scale. The characteristic stratigraphic architecture depicted in the previous sections indicates that the Po River system was subject to nearly continuous aggradation during the late Pleistocene, with poor evidence of degradational stacking (Figs. 6-10). Similar to the late Pleistocene Rhine-Meuse system (see Wallinga et al., 2004), subsidence was likely the dominant factor in the continued accommodation generated in the Po system under both sea-level fall (MIS 4 and MIS 3) and lowstand (MIS 2) conditions, which in general prevented formation of deep valleys. A similar high-accommodation scenario due to tectonics, with a lack of prominent incision and a lack of mature paleosols, was set out for a Carboniferous example (Davies and Gibling, 2003).

The two most prominent stratigraphic markers outlined in this work (LGM and YD paleosols in Figs. 6-10) have the same age and similar characteristics as paleosols "P3" and "P/H" recently reported from the Reno River basin, a tributary of the Po River, close to the Apennine foothills (Bologna area, in Fig. 1), and dated to ca. 29-26 ka (P3) and 13-11 ka (P/H), respectively (Amorosi et al., 2014). Though the linkage between Po River and its tributaries is beyond the scope of this paper, stratigraphic correlation of these paleosols over distances of several tens of kilometers and across separate fluvial domains suggests a possible allogenic control on paleosol architecture.

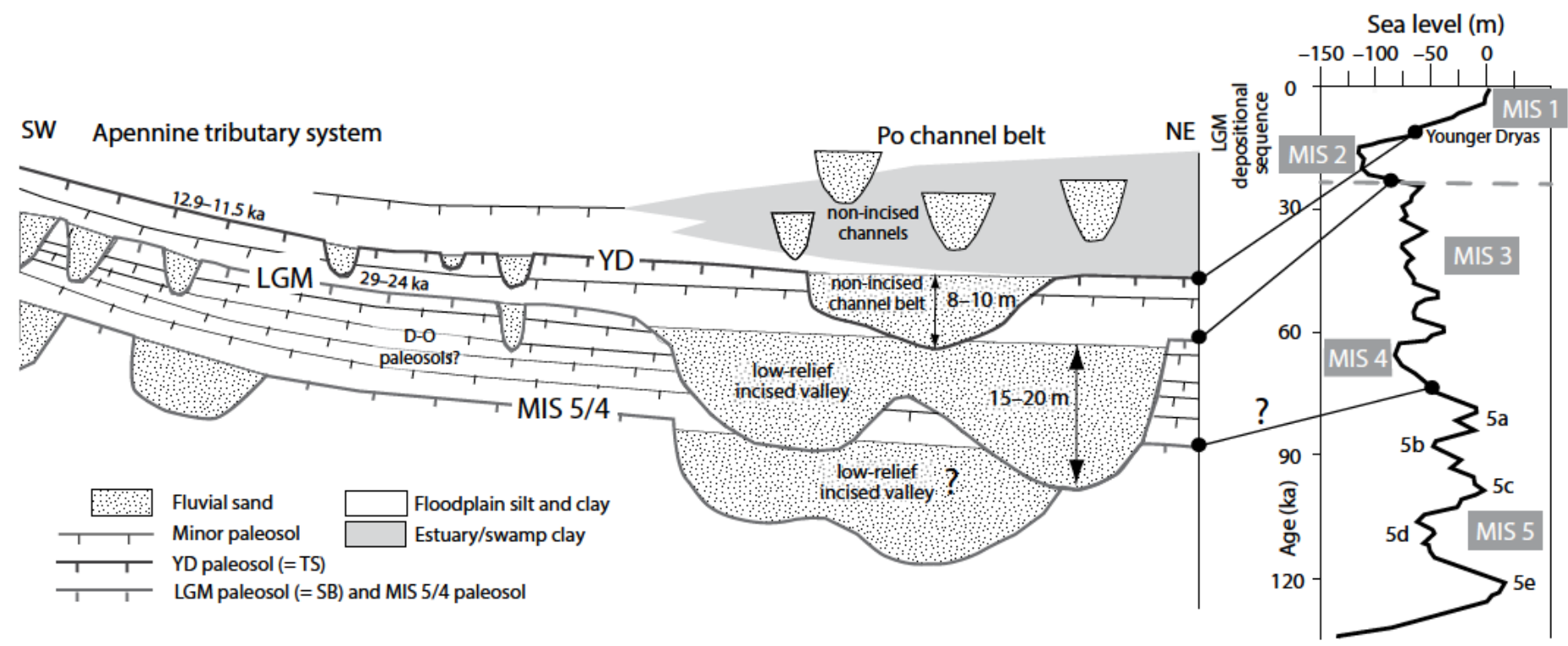

Figure 10. Simplified architecture of the late Pleistocene Po alluvial system, showing distinct types of fluvial sand bodies, paleosols, and their relationship to the sea-level curve of Bard et al. (1990). A shallow incised valley is reconstructed at the marine (oxygen) isotope stage (MIS) 3-2 transition, and inferred at the MIS 5-4 boundary (uncertain correlation is expressed as question marks). LGM-Last Glacial Maximum, YD—Younger Dryas, D-O—Dansgaard-Oeschger, SB-sequence boundary, TS—transgressive surface. 
Based on the age of the LGM paleosol and its coeval, shallow paleovalley system (Fig. 10), we hypothesize with reasonable confidence that fluvial incision took place in response to rapid climate change at the culminating regressive phase of the MIS 3-2 transition, which saw the onset of fully glacial conditions (Lambeck et al., 2002; Siddall et al., 2003). However, at that time, the shoreline position was $\sim 300 \mathrm{~km}$ from the modern shoreline, so an overprint by sea-level lowering along the low-gradient Adriatic shelf cannot be ruled out. A relative fall in sea level of $33 \mathrm{~m}$, from -74 to $-107 \mathrm{~m}$, was associated with the MIS 3-2 transition (Cutler et al., 2003), and such a sea-level fall might have enhanced the amount of fluvial incision. Channel entrenchment between 30 and 24 k.y. B.P. has also been reported in a detailed study of the Rhine-Meuse system (Busschers et al., 2005, 2007), and from other coeval incised-valley systems around the world (Dabrio et al., 2000; Wellner and Bartek, 2003; Anderson et al., 2004; Blum et al., 2008; Kasse et al., 2010; Amorosi et al., 2013), reinforcing the hypothesis of an external forcing on LGM paleosol development.

A significantly different interpretation is offered for the more immature YD paleosol, which developed at the Pleistocene-Holocene boundary (with no associated sea-level change), and for which changes in climate and sediment supply appear to have been the driving factors. The shorter term over which the YD paleosol was formed, coincident with the YD cold reversal, is consistent with subsurface stratigraphy, which shows a generally narrower YD Po channel-belt sand body compared to the LGM channel belt (Figs. 6-10). Increased erosion and sediment flux in response to the YD cold event have been reported from several coastal systems (Abdulah et al., 2004; Anderson et al., 2004; Berné et al., 2007; Pellegrini et al., 2015; Amorosi et al., 2016). In the central Adriatic, this period of extreme climatic instability led to the accumulation of a $>10$-m-thick prograding wedge recognized through high-resolution seismic profiles (middle transgressive systems tract [TST] unit of Cattaneo and Trincardi, 1999; Maselli et al., 2011), which is interpreted as the marine equivalent of the YD channel belt.

Concerning the pre-LGM portion of the stratigraphic record, this sedimentary succession is associated with large chronologic uncertainties that render comparisons of soil development with sea-level and climate changes uncertain. Based on ${ }^{14} \mathrm{C}$ dating, the MIS 3-2 (LGM) paleosol is underlain by a series of immature paleosols that formed during MIS 3 and older periods, possibly starting with the MIS 5-4 transition (see Törnqvist et al., 2003). These paleosols, which are evenly spaced and which developed during short intervals of time (a few thousand years), might represent the effect of multiple climatic variations, with successive, short-lived episodes of soil development punctuated by aggradation phases. A corollary of this interpretation is that climate oscillations such as Dansgaard-Oeschger (D-O) events could have affected fluvial sedimentation during MIS 4 and MIS 3, giving rise to a sedimentary record highly punctuated by paleosol-bearing cycles (Wallinga et al., 2004). A definitive test for this hypothesis, however, requires refinement with a larger (chronologic and geochemical) data set than the one available at present.

\section{IMPLICATIONS FOR SEQUENCE STRATIGRAPHY}

The ability to identify a conformable depositional sequence is dependent on the resolution of the data presented, and very high-resolution data sets, such as those presented here, may affect the sequence-stratigraphic hierarchy and the recognition of the key bounding surfaces (Neal and Abreu, 2009). In this regard, the late Quaternary depositional sequence of the Po Plain, developed on a time scale of a few tens of thousands of years, represents an end member for temporal resolution in sequence stratigraphy.

For the late Quaternary, it is well established that 100 k.y. glacio-eustatic fluctuations were markedly asymmetric, with long phases of relative sea-level fall followed by short periods of stabilization and rise (Chappell and Shackleton, 1986). In particular, the creation of thick ice sheets caused a worldwide, late Pleistocene (post-120 k.y. B.P.) sea-level drop of $\sim 120 \mathrm{~m}$ in 90 k.y., and the transition from interglacial to glacial conditions occurred in a stepwise fashion, with three distinct phases of sea-level fall, at the MIS 5e-5d, MIS 5-4, and MIS 3-2 transitions (Fig. 10), respectively (Waelbroeck et al., 2002). This higher-resolution view of the late Pleistocene depositional sequence (fourthorder sequence of Wornardt and Vail, 1991) implies that at least three separate stratigraphic unconformities might have formed during the glacial to interglacial transition, each having the significance of a sequence boundary (see the aggradational-degradational rhythms of Gibling et al., 2011).

The documented presence of several internal unconformities within the late Pleistocene depositional sequence provides the path to turn a low-resolution stratigraphic framework into a high-resolution one (Neal and Abreu, 2009). Particularly, evidence of degradational stacking at the MIS 3-2 transition supports interpretation of the prominent LGM paleosol (and associated bounding surface of the LGM channel belt) as the sequence boundary of a higher-resolution (fifth-order) depositional sequence ("Stage 2 sequence boundary" of Anderson et al., 2004; Fig. 10 herein). The "LGM depositional sequence" spans less than 30 k.y., which is probably the shortest time interval stratigraphically equivalent to a depositional sequence (Neal and Abreu, 2009).

On a basin scale, the amalgamated, sheetlike fluvial bodies that overlie the LGM unconformity represent the proximal feeder system of the thick prograding delta that developed in the mid-Adriatic shelf under sea-level lowstand conditions (Amorosi et al., 2016).

The YD paleosol has very high correlation potential, being marked by the sharp contrast between well-drained floodplain deposits and extensive, organic-rich, paludal and estuarine facies (Figs. 7-9). This hiatal surface, marking the base of a retrogradationally stacked stratal succession (Fig. 10), virtually coincides with the transgressive surface (Amorosi et al., 2016). Above the YD paleosol, fluvial channels become isolated in a mud-prone Holocene unit, with poor channel-belt development. This stratigraphic motif is interpreted to reflect increased accommodation rate during rapidly rising sea level (Bruno et al., 2016), and it corresponds to the classic transgressive and highstand systems tracts.

\section{CONCLUSIONS}

We applied the principles of pedostratigraphy to a large sector of the Po Plain to construct a realistic subsurface model of paleosol-channel belt sand body relationships from a rapidly subsiding basin. To this purpose, we selected the late Pleistocene to Holocene stratigraphic record of the southern Po Plain as a chronologically well-constrained example of nonmarine architecture. Since paleosol characteristics may vary depending on their paleolandscape position, we used an allostratigraphic approach built primarily on stratigraphic position of paleosols, rather than on individual soil features. The major outcomes of this work can be summarized as follows.

(1) The stratigraphic architecture of the late Pleistocene fluvial succession in the rapidly subsiding Po Basin consists of a series of aggradationally stacked, locally amalgamated channel-belt sand bodies in lieu of a well-defined paleovalley system underlain by a composite valley-fill unconformity. Channel bodies are focused beneath the modern Po River and provide a nearly continuous record of falling-stage and lowstand fluvial sedimentation spanning the entire glacial interval (MIS 4 to MIS 2), with poor evidence of degradational architecture. 
(2) A set of regionally mappable, weakly developed paleosols (Inceptisols) was identified and traced for tens of kilometers across a wide portion of the Po Plain, from the modern Po River to the Apennine margin. The most prominent paleosol developed at the onset of the LGM, i.e., during a period of abrupt climate cooling associated with significant sea-level drop. The YD paleosol is less developed than the LGM paleosol, and its evolution was mainly driven by climate forcing.

(3) Basin-scale correlations permit an unequivocal link to be established between paleosol development and generation of channel-belt sand bodies. No mature paleosol (the interfluve sequence boundary of classic sequence-stratigraphic models) was observed in cored intervals. Cumulative paleosols (such as the LGM paleosol), made up of vertically stacked, weakly developed paleosols separated by thin, nonpedogenized intervals, are invariably coupled to the largest channel-belt sand bodies, reflecting sedimentation in shallowly incised valleys, whereas paleosols with simple soil profiles (e.g., the YD paleosol) correlate with narrower channel belts, formed over shorter periods of time, and are not associated with significant fluvial incision.

(4) This paper shows that in a high-accommodation fluvial setting, sea-level fall may result in very minor or no degradation. In the Po system, updip of the Holocene estuarine-deltaic sediment wedge, where the long-valley ("equilibrium") profile of the fluvial system extends and under conditions of high sediment flux, the system could be expected not to degrade or incise.

(5) In the late Quaternary record, weakly developed paleosols delineate stratigraphic surfaces that approximate time lines and may allow continuous, high-resolution reconstruction of alluvial architecture. Owing to their distinctive engineering properties, unconsolidated successions of paleosols can readily be delineated based on CPTU and PP tests inferred from conventional core descriptions, thus facilitating stratigraphic correlation based on continuous core analysis.

(6) Through a chronologically well-constrained case study related to the last 40 k.y., this paper contributes new data to a surprisingly poor database on paleosol-channel belt relationships of late Quaternary deposits. Weakly developed paleosols are traditionally neglected in sequence stratigraphy, but they represent stratigraphic markers that may help disentangle subsurface alluvial architecture of unconsolidated deposits with unprecedented fidelity and level of detail, representing possible modern analogs for the interpretation of ancient successions. We expect that the stratigraphic approach to mapping of weakly developed paleosols will open up a new area of application to the sequence stratigraphy of buried Quaternary nonmarine successions.

\section{ACKNOWLEDGMENTS}

This study was partly supported by ExxonMobil Upstream Research Company, Spring, Texas, USA. We are indebted to Kevin Bohacs, Tina Drexler, and Joe Macquaker (ExxonMobil Upstream Research Company) for valuable tips and fruitful discussions. We thank Paolo Severi (Regione Emilia-Romagna [RER]) for access to the RER stratigraphic database and to selected cores. We also thank Howard Feldman (ExxonMobil Upstream Research Company) for criticism and comments, which improved an early version of this paper. This paper greatly benefited from comments by referees Martin Gibling and Guy Plint.

\section{REFERENCES CITED}

Abdulah, K.C., Anderson, J.B., Snow, J N., and HoldfordJack, L., 2004, The late Quaternary Brazos and Colorado deltas, offshore Texas: Their evolution and the factors that controlled their deposition, in Anderson, J.B., and Fillon, R.H., eds., Late Quaternary Stratigraphic Evolution of the Northern Gulf of Mexico Margin: Society for Sedimentary Geology Special Publication 79, p. 237-269.

AGIP, 1977, Temperature Sotterranee: Inventario dei Dati Raccolti dall'AGIP durante la Ricerca e la Produzione di Idrocarburi in Italia: Milano, Edizioni AGIP, 1930 p.

AGIP Mineraria, 1959, Campi gassiferi padani, in Atti del Convegno su Giacimenti Gassiferi dell'Europa Occidentale (Milano, 30 September-5 October 1957): Milano, Accademia Nazionale dei Lincei ed Ente Nazionale Idrocarburi (ENI), v. 2, p. 45-497.

Aitken, J.F., and Flint, S.S., 1996, Variable expressions of interfluvial sequence boundaries in the Breathitt Group (Pennsylvanian), eastern Kentucky, USA, in Howell, J.A., and Aitken, J.F., eds., High Resolution Sequence Stratigraphy: Innovations and Applications: Geological Society of London Special Publication 104, p. 193206, doi:10.1144/GSL.SP.1996.104.01.12.

Amorosi, A., and Marchi, N., 1999, High-resolution sequence stratigraphy from piezocone tests: An example from the late Quaternary deposits of the southeastern Po Plain: Sedimentary Geology, v. 128 , no. 1-2, p. $67-$ 81, doi:10.1016/S0037-0738(99)00062-7.

Amorosi, A., Colalongo, M.L., Pasini, G., and Preti, D., 1999, Sedimentary response to late Quaternary sealevel changes in the Romagna coastal plain (northern Italy): Sedimentology, v. 46, no. 1, p. 99-121, doi:10 1046/j.1365-3091.1999.00205.x.

Amorosi, A., Centineo, M.C., Colalongo, M.L., Pasini, G., and Sarti, G., 2003, Facies architecture and latest Pleistocene-Holocene depositional history of the Po Delta (Comacchio area, Italy): The Journal of Geology, v. 111, no. 1, p. 39-56, doi:10.1086/344577.

Amorosi, A., Colalongo, M.L., Fiorini, F., Fusco, F., Pasini, G., Vaiani, S.C., and Sarti, G., 2004, Palaeogeographic and palaeoclimatic evolution of the Po Plain from 150-ky core records: Global and Planetary Change, v. 40, no. 1-2, p. 55-78, doi:10.1016/S0921-8181 (03)00098-5.

Amorosi, A., Centineo, M.C., Colalongo, M.L., and Fiorini, F., 2005, Millennial-scale depositional cycles from the Holocene of the Po Plain, Italy: Marine Geology, v. $222-223$, p. $7-18$, doi:10.1016/j.margeo.2005.06 .041

Amorosi, A., Pavesi, M., Ricci Lucchi, M., Sarti, G., and Piccin, A., 2008, Climatic signature of cyclic fluvial architecture from the Quaternary of the central Po Plain, Italy: Sedimentary Geology, v. 209, no. 1-4, p. 58-68, doi:10.1016/j.sedgeo.2008.06.010.

Amorosi, A., Rossi, V., Sarti, G., and Mattei, R., 2013 , Coalescent valley fills from the late Quaternary record of Tuscany (Italy): Quaternary International, v. 288, p. 129-138, doi:10.1016/j.quaint.2011.10.015.
Amorosi, A., Bruno, L., Rossi, V., Severi, P., and Hajdas, I., 2014, Paleosol architecture of a late Quaternary basin-margin sequence and its implications for highresolution, non-marine sequence stratigraphy: Global and Planetary Change, v. 112, p. 12-25, doi:10.1016/j .gloplacha.2013.10.007.

Amorosi, A., Bruno, L., Campo, B., and Morelli, A., 2015, The value of pocket penetration tests for the highresolution palaeosol stratigraphy of late Quaternary deposits: Geological Journal, v. 50, p. 670-682, doi: 10.1002/gj.2585

Amorosi, A., Maselli, V., and Trincardi, F., 2016, Onshore to offshore anatomy of a late Quaternary source-to-sink system (Po Plain-Adriatic Sea, Italy): Earth-Science Reviews, v. 153 , p. 212-237, doi:10.1016/j.earscirev .2015.10.010

Anderson, J.B., Rodriguez, A., Abdulah, K.C., Fillon, R.H., Banfield, L.A., McKeown, H.A., and Wellner, J.S., 2004, Late Quaternary stratigraphic evolution of the northern Gulf of Mexico margin: A synthesis, in Anderson, J.B., and Fillon, R.H., eds., Late Quaternary Stratigraphic Evolution of the Northern Gulf of Mexico Margin: Society for Sedimentary Geology Special Publication 79, p. 1-23.

Atchley, S.C., Nordt, L.C., and Dworkin, S.I., 2004, Eustatic control on alluvial sequence stratigraphy: A possible example from the Cretaceous-Tertiary transition of the Tornillo Basin, Big Bend National Park, West Texas, U.S.A.: Journal of Sedimentary Research, v. 74, no. 3, p. 391-404, doi:10.1306/102203740391.

Atchley, S.C., Nordt, L.C., Dworkin, S.I., Cleveland, D M. Mintz, J.S., and Hunter Harlow, R., 2013, Alluvial stacking pattern analysis and sequence stratigraphy: Concepts and case studies, in Driese, S.C., Nordt, L.C., and McCarthy, P.J., eds., New Frontiers in Paleopedology and Terrestrial Paleoclimatology: Paleosols and Soil Surface Analog Systems: Society for Sedimentary Geology Special Publication 104, p. 109-129, doi:10 .2110/sepmsp.104.13

Bard, E., Hamelin, B., and Fairbanks, R.G., 1990, U-Th ages obtained by mass spectrometry in corals from Barbados: Sea level during the past 130,000 years: Nature, v. 346, p. 456-458, doi:10.1038/346456a0.

Berger, G.W., Pillans, B.J., Bruce, J.G., and McIntosh, P.D. 2002, Luminescence chronology of loess-paleosol sequences from southern South Island, New Zealand: Quaternary Science Reviews, v. 21, no. 16-17, p. 1899-1913, doi:10.1016/S0277-3791(02)00021-5.

Berné, S., Jouet, G., Bassetti, M.A., Dennielou, B., and Taviani, M., 2007, Late Glacial to Preboreal sea-level rise recorded by the Rhône deltaic system (NW Mediterranean): Marine Geology, v. 245, p. 65-88, doi:10 .1016/j.margeo.2007.07.006.

Bestland, E.A., 1997, Alluvial terraces and paleosols as indicators of early Oligocene climate change (John Day Formation, Oregon): Journal of Sedimentary Research, v. 67 , no. 5 , p. $840-855$, doi:10.1306/D4268653-2B26 $-11 \mathrm{D} 7-8648000102 \mathrm{C} 1865 \mathrm{D}$

Blum, M.D., and Törnqvist, T.E., 2000, Fluvial response to climate and sea level change: A review and look forward: Sedimentology, v. 47, p. $2-48$, doi: $10.1046 / \mathrm{j}$ .1365-3091.2000.00008.x

Blum, M.D., Tomkin, J.H., Purcell, A., and Lancaster, R.R. 2008, Ups and downs of the Mississippi Delta: Geology, v. 36, no. 9, p. 675-678, doi:10.1130/G24728A.1.

Blum, M.D., Martin, J., Milliken, K., and Garvin, M., 2013 Paleovalley systems: Insights from Quaternary analogs and experiments: Earth-Science Reviews, v. 116, p. 128-169, doi:10.1016/j.earscirev.2012.09.003.

Bown, T.M., and Kraus, M.J., 1981, Lower Eocene alluvial paleosols (Willwood Formation, northwest Wyoming, U.S.A.) and their significance for paleoecology, paleoclimatology and basin analysis: Palaeogeography, Palaeoclimatology, Palaeoecology, v. 34, p. 1-30, doi 10.1016/0031-0182(81)90056-0.

Boyd, R., Dalrymple, R.W., and Zaitlin, B.A., 2006, Estuarine and incised-valley facies models, in Posamentier, H.W., and Walker, R.G., eds., Facies Models Revisited: Society for Sedimentary Geology Special Publication 84, p. 171-235, doi:10.2110/pec.06.84.0171.

Bruno, L., Amorosi, A., Severi, P., and Costagli, B., 2016, Late Quaternary aggradation rates and stratigraphic 
architecture of the southern Po Plain, Italy: Basin Research (in press), doi: 10.1111/bre.12174

Buol, S.W., Southard, R.J., Graham, R.C., and McDaniel, P.A., 2011, Soil Genesis and Classification (6th ed.): Chichester, UK, Wiley-Blackwell, 543 p., doi:10.1002 19780470960622

Busschers, F.S., Weerts, H.J.T., Wallinga, J., Cleveringa, P., Kasse, C., de Wolf, H., and Cohen, K.M., 2005 , Sedimentary architecture and optical dating of middle and late Pleistocene Rhine-Meuse deposits-Fluvial response to climate change, sea-level fluctuation and glaciation: Netherlands Journal of Geosciences, v. 84 no. 1, p. $25-41$

Busschers, F.S., Kasse, C., van Balen, R.T., Vandenberghe, J., Cohen, K.M., Weerts, H.J.T., Wallinga, J., Johns, C., Cleveringa, P., and Bunnik, F.P M., 2007, Late Pleistocene evolution of the Rhine-Meuse system in the southern North Sea basin: Imprints of climate change, sea-level oscillation, and glacio-isostasy: Quaternary Science Reviews, v. 26, no. 25-28, p. 3216-3248, doi: 10.1016/j.quascirev.2007.07.013.

Castellarin, A., Eva, C., Giglia, G., and Vai, G.B., 1985 , Analisi strutturale del Fronte Appenninico Padano: Giornale di Geologia, v. 47, no. 1-2, p. 47-75.

Cattaneo, A., and Trincardi, F., 1999, The late Quaternary transgressive record in the Adriatic epicontinental sea: Basin widening and facies partitioning, in Bergman, K.M., and Snedden, J.W., eds., Isolated Shallow Marine Sand Bodies: Sequence Stratigraphic Analysis and Sedimentological Interpretation: Society for Sedimentary Geology Special Publication 64, p. 127-146, doi: 10.2110/pec.99.64.0127.

Chappell, J., and Shackleton, N.J., 1986, Oxygen isotope and sea level: Nature, v. 324, p. 137-140, doi:10.1038 1324137a0.

Choi, K., and Kim, J.H., 2006, Identifying late Quaternary coastal deposits in Kyonggi Bay, Korea, by their geotechnical properties: Geo-Marine Letters, v. 26, no. 2 , p. 77-89, doi:10.1007/s00367-006-0018-2.

Cleveland, D M., Atchley, S.C., and Nordt, L.C., 2007, Continental sequence stratigraphy of the Upper Triassic (Norian-Rhaetian) Chinle strata, northern New Mexico, U.S.A.: Allocyclic and autocyclic origins of paleosol-bearing alluvial successions: Journal of Sedimentary Research, v. 77, no. 11, p. 909-924, doi:10 $.2110 /$ jsr.2007.082

Cutler, K.B., Edwards, R.L., Taylor, F.W., Cheng, H., Adkins, J., Gallup, C.D., Cutler, PM., Burr, G.S., and Bloom, A.L., 2003, Rapid sea-level fall and deep-ocean temperature change since the last interglacial period: Earth and Planetary Science Letters, v. 206, no. 3-4, p. 253-271, doi:10.1016/S0012-821X(02)01107-X

Dabrio, C.J., Zazo, C., Goy, J.L., Sierro, F.J., Borja, F., Lario, J., González, J.A., and Flores, J.A., 2000, Depositional history of estuarine infill during the last postglacial transgression (Gulf of Cadiz, southern Spain): Marine Geology, v. 162 , no. 2-4, p. $381-404$, doi:10 .1016/S0025-3227(99)00069-9.

Dalrymple, R.W., Boyd, R., and Zaitlin, B.A., 1994, History of research, types and internal organization of incised-valley systems: Introduction to the volume, in Dalrymple, R.W., Boyd, R., and Zaitlin, B.A., eds. Incised-Valley Systems: Origin and Sedimentary Sequences: Society for Sedimentary Geology Special Publication 51, p. 3-10.

Davies, S.J., and Gibling, M.R., 2003, Architecture of coastal and alluvial deposits in an extensional basin: The Carboniferous Joggins Formation of eastern Canada: Sedimentology, v. 50 , p. $415-439$, doi:10.1046/j .1365-3091.2003.00553.x.

Demko, T.M., Currie, B.S., and Nicoll, K.A., 2004, Regional paleoclimatic and stratigraphic implications of paleosols and fluvial/overbank architecture in the Morrison Formation (Upper Jurassic), Western Interior, USA: Sedimentary Geology, v. 167 , no. 3-4, p. 115-135, doi 10.1016/j.sedgeo.2004.01.003

Doglioni, C., 1993, Some remarks on the origin of foredeeps: Tectonophysics, v. 228, no. 1-2, p. 1-20, doi: 10 .1016/0040-1951(93)90211-2.

Dubiel, R.F., and Hasiotis, S.T., 2011, Deposystems, paleosols, and climatic variability in a continental system: The Upper Triassic Chinle Formation, Colorado Pla- teau, U.S.A in Davidson, S.K., Leleu, S., and North, C.P., eds., From River to Rock Record: The Preservation of Fluvial Sediments and their Subsequent Interpretation: Society for Sedimentary Geology Special Publication 97, p. 393-421.

Eppes, M.C., Bierma, R., Vinson, D., and Pazzaglia, F. 2008, A soil chronosequence study of the Reno valley, Italy: Insights into the relative role of climate versus anthropogenic forcing on hillslope processes during the mid-Holocene: Geoderma, v. 147 , no. $3-4$, p. 97 107, doi:10.1016/j.geoderma.2008.07.011

Feng, Z.D., and Wang, H.B., 2005, Pedostratigraphy and carbonate accumulation in the last interglacial pedocomplex of the Chinese Loess Plateau: Soil Science Society of America Journal, v. 69, no. 4, p. 1094-1101, doi:10.2136/sssaj2004.0078.

Flaig, P.P., McCarthy, P.J., and Fiorillo, A.R., 2013, Anatomy, evolution, and paleoenvironmental interpretation of an ancient Arctic coastal plain: Integrated paleopedology and palynology from the Upper Cretaceous (Maastrichtian) Prince Creek Formation, North Slope, Alaska, USA, in Driese, S.C., Nordt, L.C., and McCarthy, PJ., eds., New Frontiers in Paleopedology and Terrestrial Paleoclimatology: Paleosols and Soil Surface Analog Systems: Society for Sedimentary Geology Special Publication 104, p. 179-230, doi:10.2110 /sepmsp.104.14.

Gibling, M.R., and Bird, D.J., 1994, Late Carboniferous cyclothems and alluvial paleovalleys in the Sydney Basin, Nova Scotia: Geological Society of America Bulletin, v. 106, no. 1, p. 105-117, doi:10.1130/0016 $-7606(1994) 106<0105 \cdot$ LCCAAP $>2.3 . \mathrm{CO} \cdot 2$

Gibling, M.R., and Wightman, W.G., 1994, Palaeovalleys and protozoan assemblages in a late Carboniferous cyclothem, Sydney Basin, Nova Scotia: Sedimentology, v. 41, no. 4, p. 699-719, doi:10.1111/j.1365-3091 1994.tb01418.x.

Gibling, M.R., Fielding, C.R., and Sinha, R., 2011, Alluvial valleys and alluvial sequences: Towards a geomorphic assessment, in Davidson, S.K., Leleu, S., and North, C.P., eds., From River to Rock Record: The Preservation of Fluvial Sediments and their Subsequent Interpretation: Society for Sedimentary Geology Special Publication 97, p. 423-447, doi:10.2110/sepmsp.097 423

Hartley, A.J., Weissman, G.S., Bhattacharayya, P., Nichols, G.J., Scuderi, L.A., Davidson, S.K., Leleu, S., Chakraborty, T., Ghosh, P., and Mather, A.E., 2013, Soil development on modern distributive fluvial systems: Preliminary observations with implications for interpretation of paleosols in the rock record, in Driese, S.C., Nordt, L.C., and McCarthy, P.J., eds., New Frontiers in Paleopedology and Terrestrial Paleoclimatology: Paleosols and Soil Surface Analog Systems: Society for Sedimentary Geology Special Publication 104, p. 149-158, doi:10.2110/sepmsp.104.10.

Holbrook, J., 2001, Origin, genetic interrelationships, and stratigraphy over the continuum of fluvial channelform bounding surfaces: An illustration from middle Cretaceous strata, southeastern Colorado: Sedimentary Geology, v. 144, no. 3-4, p. 179-222, doi:10.1016 /S0037-0738(01)00118-X

Kasse, C., Bohncke, S.J.P., Vandenberghe, J., and Gábris, G., 2010, Fluvial style changes during the last glacialinterglacial transition in the middle Tisza valley (Hungary): Proceedings of the Geologists' Association, v. 121 , no. 2, p. 180-194, doi:10.1016/j.pgeola.2010 .02 .005

Kemp, R.A., Derbyshire, E., Xingmin, M., Fahu, C., and Baotian, P., 1995, Pedosedimentary reconstruction of a thick loess-palaeosol sequence near Lanhzou in north-central China: Quaternary Research, v. 43, no. 1 , p. 30-45, doi:10.1006/qres.1995.1004

Kemp, R.A., Zárate, M., Toms, P., King, M., Sanabria, J., and Arguello, G., 2006, Late Quaternary paleosols, stratigraphy and landscape evolution in the northern Pampa, Argentina: Quaternary Research, v. 66, no. 1, p. 119-132, doi:10.1016/j.yqres.2006.01.001.

Kraus, M.J., 1999, Paleosols in clastic sedimentary rocks: Their geologic applications: Earth-Science Reviews, v. 47 , no. $1-2$, p. $41-70$, doi: $10.1016 /$ S0012-8252 (99)00026-4.
Kraus, M.J., 2002, Basin-scale changes in floodplain paleosols: Implications for interpreting alluvial architecture: Journal of Sedimentary Research, v. 72, no. 4, p. 500509, doi:10.1306/121701720500.

Kraus, M.J., and Aslan, A., 1999, Paleosol sequences in floodplain environments: A hierarchical approach, in Thiry, M., and Simon-Coinçon, R., eds., Palaeoweathering, Palaeosurfaces and Related Continenta Deposits: International Association of Sedimentologists Special Publication 27, p. 303-321, doi:10.1002 /9781444304190.ch12.

Kraus, M.J., and Bown, T.M., 1993, Palaeosols and sandbody prediction in alluvial sequences, in North, C.P. and Prosser, D.J., eds., Characterization of Fluvial and Aeolian Reservoirs: Geological Society of London Special Publication 73, p. 23-31, doi:10.1144/GSL.SP .1993.073.01.03.

Lafuerza, S., Canals, M., Casamor, J.L., and Devincenzi, J M., 2005, Characterization of deltaic sediment bodies based on in situ CPT/CPTU profiles: A case study on the Llobregat delta plain, Barcelona, Spain: Marine Geology, v. 222-223, p. 497-510, doi:10.1016/j margeo.2005.06.043.

Lambeck, K., Yokoyama, Y., and Purcell, T., 2002, Into and out of the Last Glacial Maximum: Sea-level change during oxygen isotope stages 3 and 2: Quaternary Science Reviews, v. 21 , no. $1-3$, p. 343-360, doi:10.1016 /S0277-3791(01)00071-3.

Mahaney, W.C., Andres, W., and Barendregt, R.W., 1993, Quaternary paleosol stratigraphy and paleomagnetic record near Dreihausen, central Germany: Catena, v. 20 , no. $1-2$, p. 161-177, doi:10.1016/0341-8162 (93) $90035-\mathrm{N}$

Maselli, V., Hutton, E.W., Kettner, A.J., Syvitski, J.P.M., and Trincardi, F., 2011, High-frequency sea level and sediment supply fluctuations during Termination I: An integrated sequence-stratigraphy and modeling approach from the Adriatic Sea (central Mediterranean): Marine Geology, v. 287, no. 1-4, p. 54-70, doi:10.1016/j margeo.2011.06.012.

McCarthy, P.J., and Plint, A.G., 1998, Recognition of interfluve sequence boundaries: Integrating paleopedology and sequence stratigraphy: Geology, v. 26, no. 5 p. 387-390, doi:10.1130/0091-7613(1998)026<0387: ROISBI>2.3.CO;2.

McCarthy, P.J., and Plint, A.G., 2003, Spatial variability of palaeosols across Cretaceous interfluves in the Dunvegan Formation, NE British Columbia, Canada Palaeohydrological, palaeogeomorphological and stratigraphic implications: Sedimentology, v. 50 no. 6, p. 1187-1220, doi:10.1111/j.1365-3091.2003 $.00600 . x$.

McCarthy, P.J., and Plint, A.G., 2013, A pedostratigraphic approach to nonmarine sequence stratigraphy: A threedimensional paleosol-landscape model from the Cretaceous (Cenomanian) Dunvegan Formation, Alberta and British Columbia, Canada, in Driese, S.C., Nordt, L.C., and McCarthy, P.J., eds., New Frontiers in Paleopedology and Terrestrial Paleoclimatology: Paleosols and Soil Surface Analog Systems: Society for Sedimentary Geology Special Publication 104, p. 159-177, doi:10 .2110/sepmsp.104.02

McCarthy, P.J., Faccini, U.F., and Plint, A.G., 1999, Evolution of an ancient floodplain: Palaeosols, interfluves and alluvial architecture in a sequence stratigraphic framework, Cenomanian Dunvegan Formation, NE British Columbia, Canada: Sedimentology, v. 46, no. 5, p. 861-891, doi:10.1046/j.1365-3091.1999 .00257.x

Morrison, R.B., 1978, Quaternary soil stratigraphy-Concepts, methods, and problems, in Mahaney, W.C., ed. Quaternary Soils: Third Symposium on Quaternary Research: Norwich, UK, University of York, Geoabstracts, p. 77-108.

Morton, R.A., Suter, J.R., 1996, Sequence stratigraphy and composition of late Quaternary shelf-margin deltas, northern Gulf of Mexico: American Association of Petroleum Geologists Bulletin, v. 80, p. 505-530.

Muttoni, G., Carcano, C., Garzanti, E., Ghielmi, M., Piccin, A., Pini, R., Rogledi, S., and Sciunnach, D., 2003, Onset of major Pleistocene glaciations in the Alps: Geology, v. 31, no. 11, p. 989-992, doi:10.1130/G19445.1. 
Neal, J., and Abreu, V., 2009, Sequence stratigraphy hierarchy and the accommodation succession method: Geology, v. 37, no. 9, p. 779-782, doi:10.1130/G25722A.1.

Ori, G.G., 1993, Continental depositional systems of the Quaternary of the Po Plain (northern Italy): Sedimentary Geology, v. 83 , no. 1-2, p. 1-14, doi:10.1016 /S0037-0738(10)80001-6.

Pellegrini, C., Maselli, V., Cattaneo, A., Piva, A., Ceregato, A., and Trincardi, F., 2015, Anatomy of a compound delta from the post-glacial transgressive record in the Adriatic Sea: Marine Geology, v. 362, p. 43-59, doi:10 $.1016 /$ j.margeo.2015.01.010.

Pieri, M., and Groppi, G., 1981, Subsurface geological structure of the Po Plain, Italy, in Pieri, M., and Groppi, G., eds., Progetto Finalizzato Geodinamica 414: Rome, Consiglio Nazionale delle Ricerche, p. 1-23.

Plint, A.G., McCarthy, P.J., and Faccini, U.F., 2001, Nonmarine sequence stratigraphy: Updip expression of sequence boundaries and systems tracts in a high-resolution framework, Cenomanian Dunvegan Formation, Alberta foreland basin, Canada: American Association of Petroleum Geologists Bulletin, v. 85, no. 11, p. 1967-2001.

Ramsey, C., and Lee, S., 2013, Recent and planned developments of the program OxCal: Radiocarbon, v. 55, no. $2-3$, p. $720-730$.

Regione Emilia-Romagna and ENI-AGIP, 1998, Riserve Idriche Sotterranee della Regione Emilia-Romagna: Firenze, S.EL.CA. s.r.l., 120 p.

Regione Lombardia and E.N.I. Divisione A.G.I.P., 2002, Geologia degli acquiferi Padani della Regione Lombardia: Firenze, Italy, Società Elaborazioni Cartografiche (S.EL.CA. s.r.l.), 130 p.

Reimer, P.G., Bard, E., Bayliss, A., et al., 2013, IntCal13 and Marine13 radiocarbon age calibration curves 0-50,000 years cal BP: Radiocarbon, v. 55 , no. 4, p. 1869-1887, doi:10.2458/azu_js_rc.55.16947.

Retallack, G.J., 1983, A paleopedological approach to the interpretation of terrestrial sedimentary rocks: The mid-Tertiary fossil soils of Badlands National Park, South Dakota: Geological Society of America Bulletin, v. 94, no. 7, p. 823-840, doi:10.1130/0016-7606 (1983) $94<823$ :APATTI>2.0.CO;2.

Retallack, G.J., 2001, Soils of the Past: An Introduction to Paleopedology (2nd ed.): Oxford, UK, Blackwell, 404 p., doi:10.1002/9780470698716.

Retallack, G.J., 2012, Were Ediacaran siliciclastics of South Australia coastal or deep marine?: Sedimentology, v. 59 , no. 4 , p. $1208-1236$, doi:10.1111/j.1365-3091 .2011.01302.x

Ricci Lucchi, F., 1986, Oligocene to recent foreland basins of Northern Apennines, in Allen, P., and Homewood, P., eds., Foreland Basins: International Association of Sedimentologists Special Publication 8, p. 105-139, doi:10.1002/9781444303810.ch6.

Rosenau, N.A., Tabor, N.J., Elrick, S.D., and Nelson, W.J., 2013, Polygenetic history of paleosols in MiddleUpper Pennsylvanian cyclothems of the Illinois Basin, U.S.A.: Part I. Characterization of paleosol types and interpretation of pedogenic processes: Journal of Sedimentary Research, v. 83, no. 8, p. 606-636, doi:10 .2110/jsr.2013.50.

Sarti, G., Rossi, V., and Amorosi, A., 2012, Influence of Holocene stratigraphic architecture on ground surface settlements: A case study from the City of Pisa (Tuscany, Italy): Sedimentary Geology, v. 281, p. 75-87, doi:10.1016/j.sedgeo.2012.08.008.

Scardia, G., Muttoni, G., and Sciunnach, D., 2006, Subsurface magnetostratigraphy of Pleistocene sediments from the Po Plain (Italy): Constraints on rates of sedimentation and rock uplift: Geological Society of America Bulletin, v. 118 , no. $11-12$, p. 1299-1312, doi:10 1130/B25869.1.

Schellenberger, A., and Veit, H., 2006, Pedostratigraphy and pedological and geochemical characterization of Las Carreras loess-paleosol sequence, Valle de Tafí, NW-Argentina: Quaternary Science Reviews, v. 25, no. 7-8, p. 811-831, doi:10.1016/j.quascirev.2005.07 011 .

Shanley, K.W., and McCabe, P.J., 1994, Perspectives on the sequence stratigraphy of continental strata: American Association of Petroleum Geologists Bulletin, v. 78, no. 4 , p. 544-568.

Sheldon, N.D., and Tabor, N.J., 2009, Quantitative paleoenvironmental and paleoclimatic reconstruction using paleosols: Earth-Science Reviews, v. 95, p. 1-52, doi: 10.1016/j.earscirev.2009.03.004.

Siddall, M., Rohling, E.J., Almogi-Labin, A., Hemleben, Ch., Meischner, D., Schmelzer, I., and Smeed, D.A., 2003, Sea-level fluctuations during the last glacial cycle: Nature, v. 423 , p. $853-858$, doi: 10.1038 /nature01690.

Soil Survey Staff, 1999, Soil Taxonomy. A Basic System of Soil Classification for Making and Interpreting Soil Surveys, Agricultural Handbook 436 (2nd ed.): Washington D.C., Natural Resources Conservation Service, U.S. Department of Agriculture, 886 p.

Srivastava, P., Rajak, M.K., Sinha, R., Pal, D.K., and Bhattacharyya, T., 2010, A high-resolution micromorphological record of the late Quaternary paleosols from Ganga-Yamuna interfluve: Stratigraphic and paleoclimatic implications: Quaternary International, v. 227, no. 2, p. 127-142, doi:10.1016/j.quaint.2010.02.019.

Stefani, M., and Vincenzi, S., 2005, The interplay of eustasy, climate and human activity in the late Quaternary depositional evolution and sedimentary architecture of the Po Delta system: Marine Geology, v. 222-223, p. 19-48, doi:10.1016/j.margeo.2005.06.029

Styllas, M., 2014, A simple approach for defining Holocene sequence stratigraphy using borehole and cone penetration test data: Sedimentology, v. 61 , no. 2 , p. 444 460, doi:10.1111/sed.12061.

Tandon, S.K., and Gibling, M.R., 1994, Calcrete and coal in late Carboniferous cyclothems of Nova Scotia, Canada: Climate and sea-level changes linked: Geology, v. 22, no. 8, p. 755-758, doi:10.1130/0091-7613 (1994)022<0755:CACILC >2.3.CO;2.

Tandon, S.K., and Gibling, M.R., 1997, Calcretes at sequence boundaries in Upper Carboniferous cyclothems of the Sydney Basin, Atlantic Canada: Sedimentary Geology, v. 112, no. 1-2, p. 43-67, doi:10.1016/S0037 $-0738(96) 00092-9$.

Törnqvist, T.E., Wallinga, J., and Busschers, F.S., 2003, Timing of the last sequence boundary in a fluvial setting near the highstand shoreline-Insights from optical dating: Geology, v. 31, no. 3, p. 279-282, doi: 10.1130/0091-7613(2003)031<0279:TOTLSB > 2.0 $\mathrm{CO} ; 2$.
Trendell, A M., Atchley, S.C., and Nordt, L.C., 2012, Depositional and diagenetic controls on reservoir attributes within a fluvial outcrop analog: Upper Triassic Sonsela member of the Chinle Formation, Petrified Forest National Park, Arizona: American Association of Petroleum Geologists Bulletin, v. 96, no. 4, p. 679-707, doi: $10.1306 / 08101111025$.

Tsatskin, A., Sandler, A., and Avnaim-Katav, S., 2015, Quaternary subsurface paleosols in Haifa Bay, Israel: A new perspective on stratigraphic correlations in coastal settings: Palaeogeography, Palaeoclimatology, Palaeoecology, v. 426, p. 285-296, doi:10.1016/j.palaeo.2015 .03.018.

Ufnar, D.F., 2007, Clay coatings from a modern soil chronosequence: A tool for estimating the relative age of well-drained paleosols: Geoderma, v. 141, no. 3-4, p. 181-200, doi:10.1016/j.geoderma.2007.05.017.

Van Wagoner, J.C., Mitchum, R M., Campion, K.M., and Rahmanian, V.D., 1990, Siliciclastic Sequence Stratigraphy in Well Logs, Cores and Outcrops: Concepts for High Resolution Correlations of Time and Facies: Tulsa, American Association of Petroleum Geologists, Methods in Exploration 7, 55 p.

Waelbroeck, C., Labeyrie, L., Michel, E., Duplessy, J.C., McManus, J.F., Lambeck, K., Balbon, E., and Labracherie, M., 2002, Sea-level and deep water temperature changes derived from benthic foraminifera isotopic records: Quaternary Science Reviews, v. 21, no. 1-3, p. 295-305, doi:10.1016/S0277-3791(01)00101-9.

Wallinga, J., Törnqvist, T.E., Busschers, F.S., and Weerts, H.J.T., 2004, Allogenic forcing of the late Quaternary Rhine-Meuse fluvial record: The interplay of sea-level change, climate change and crustal movements: Basin Research, v. 16, no. 4, p. 535-547, doi:10.1111/j.1365 $-2117.2003 .00248 . x$.

Wellner, R.W., and Bartek, L.R., 2003, The effect of sea level, climate, and shelf physiography on the development of incised-valley complexes: A modern example from the East China Sea: Journal of Sedimentary Research, v. 73, no. 6, p. 926-940, doi:10.1306 1041603730926.

Wornardt, W.W., and Vail, P.R., 1991, Revision of the PlioPleistocene cycles and their application to sequence stratigraphy and shelf and slope sediments in the Gulf of Mexico: Transactions of the Gulf Coast Association of Geological Societies, v. 41, p. 719-744.

Wright, V.P., and Marriott, S.B., 1993, The sequence stratigraphy of fluvial depositional systems: The role of floodplain sediment storage: Sedimentary Geology, v. 86 , no. 3-4, p. 203-210, doi:10.1016/0037-0738 (93)90022-W.

Zhisheng, A., and Porter, S.C., 1997, Millennial-scale climatic oscillations during the last interglaciation in central China: Geology, v. 25, no. 7, p. 603-606, doi 10.1130/0091-7613(1997)025<0603:MSCODT $>2.3$ .CO;2. 